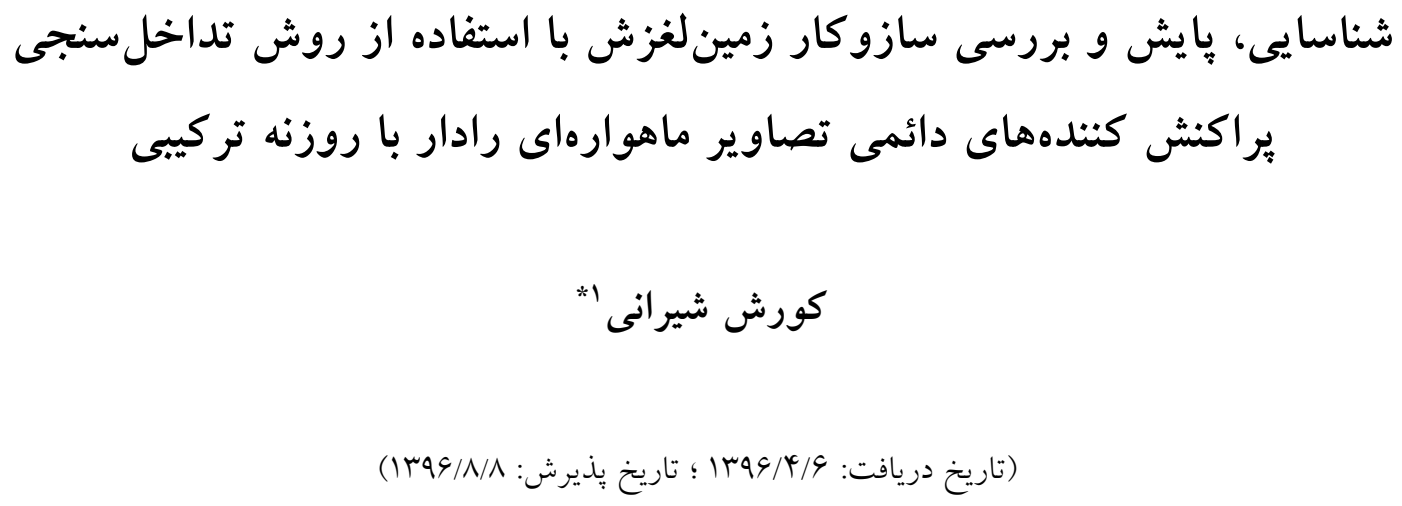

جكيده

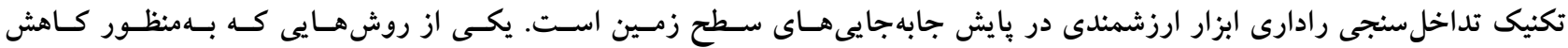

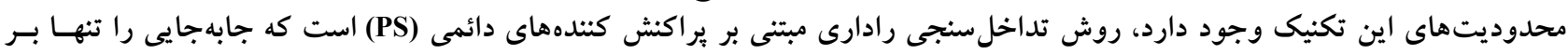

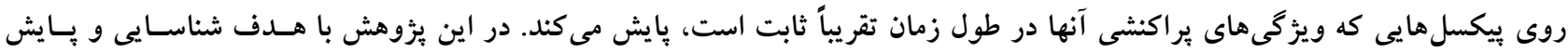

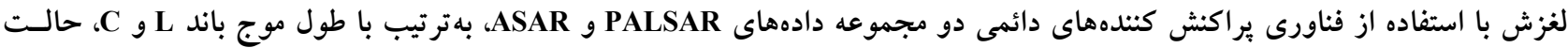

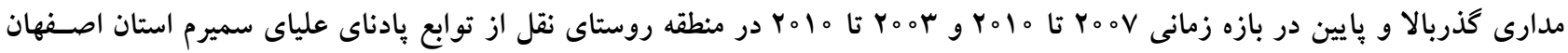

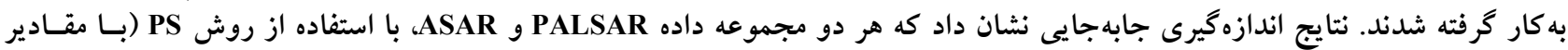

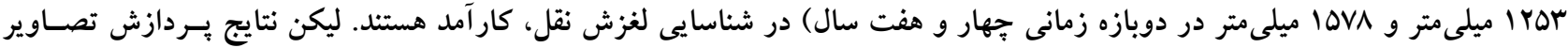

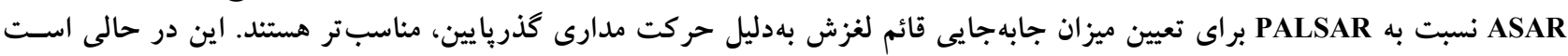

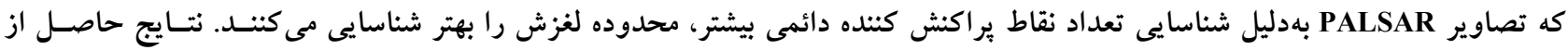

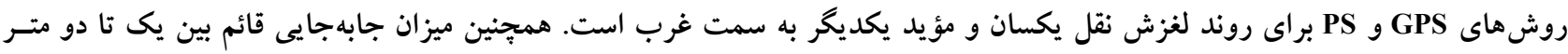

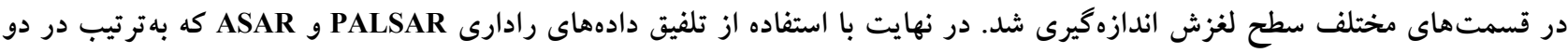

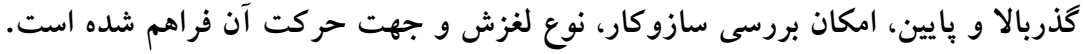

وازمهاى كليدى: تداخل سنجى، ير اكنش كندههاى دائمى، رادار، زمينلغزش، ASAR،PALSAR

1. مركز تحقيقات و آموزش كشاورزى و منابع طبيعى استان اصغهان، سازمان تحقيقات، آموزش و ترويج كشاورزى، اصفهان، ايران

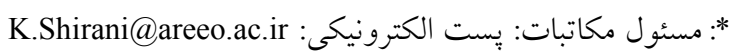


برداشتكر ليزرى زمينى استوار هستند. اين فن آورىها با وجود استحكام و قابليت اطمينانشان، زمانبر و مستلزم امكانات ويـزّه

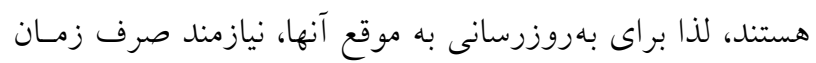
و هزينه زياد است (Yr).

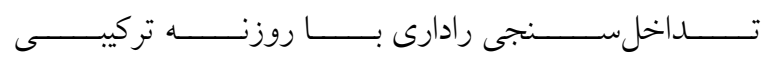
شـاخه (InSAR) (Interferometry Synthetic Aperture Radar) مهمسى از ســنش از دور اسـتـ. ايـن شـاخه در تهيـهـ نقشـهـ و

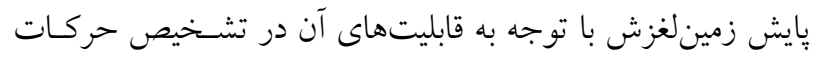

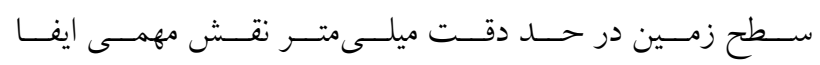

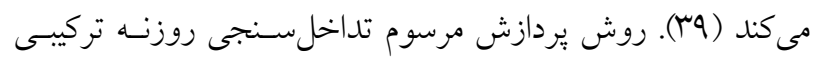
رادار (InSAR) براى تشخيص و شناسايى حركـات زمينى عمـدتاً

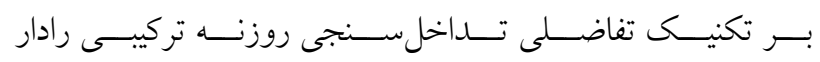
(Differential Interferometry Synthetic Aperture Radar) (DInSAR) (DInSAR)

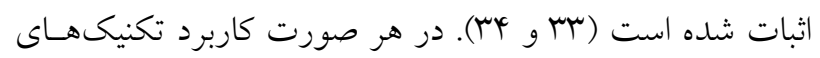

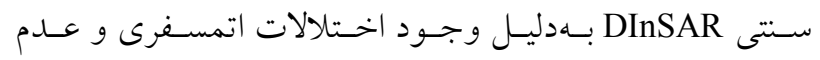

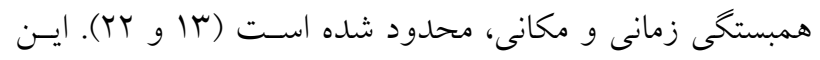

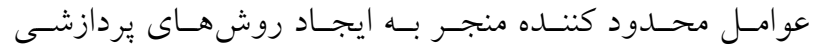
ييشرفته تر تصاوير SAR شده است. فـاز تـداخلسـنجى رادارى

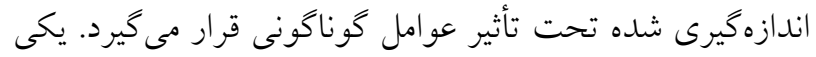
از مهم تـرين ايـن عوامـل اثـرات اتمسـفرى اسـت كـه در فــاز

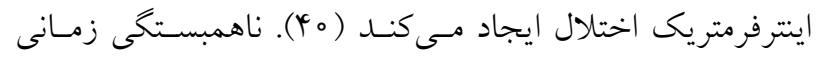

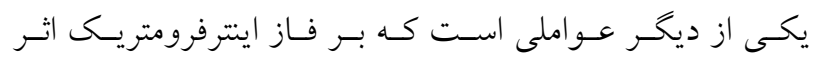

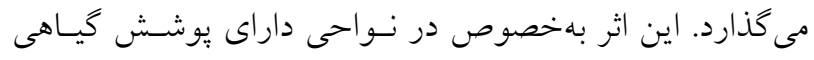

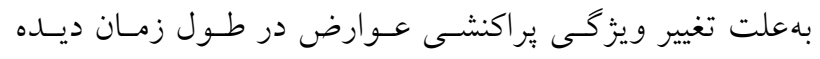

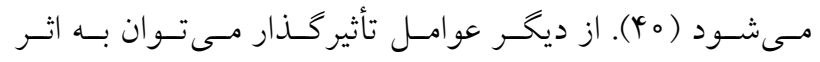

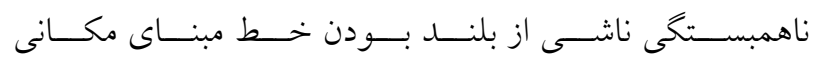

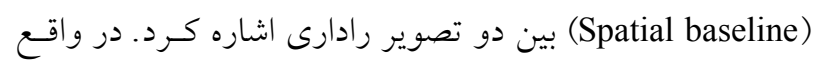

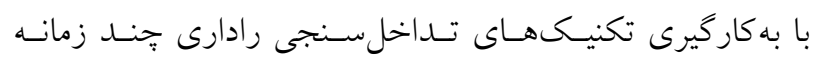
(Multi temporal InSAR techniques) ناهمبسـتخى هـاى مختلـف را روى فـاز تـداخل سـنجى رادارى
يديده زمينلغزش يا همان فرايند تدريجى حركت لايسه سـحى زمين در بسيارى از مناطق كوهستانى اتفاق مسىافتـد. ايسن يديــده بسته به وسعت مكانى و شدت جابهجايى، اثرات محيطى مختلفى

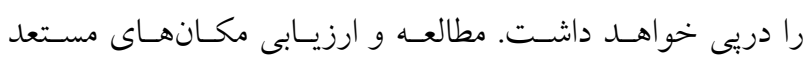
زمينلغزش و براورد ميزان جابهجـايى و فعاليـت آنها از اهميـت بهسزايى برخوردار است (و، م، 9 و 99). وقـوع زمسينلغـزش در كوهستانهاى فعال سبب فرسـايش شـديد شـكل ظـاهرى زمسين خواهد شد. علاوهبر اين، زمينلغزش يكى از مخربترين سـوانح طبيعى است كه جـان انسـانهـا و زيرسـاختهــاى شـهرى را در معرض تهديد قرار مىدهد و هر ساله سبب خسارات گسـتردهاى

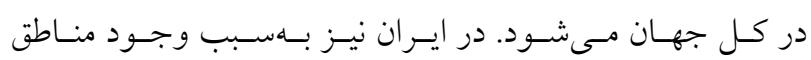
كوهستانى با شيب تند و هم:حنين فاكتورهاى تشديد كنــده نظيـر بارندگى و زمينلرزه، زمين لغزشهـاى متعـددى رخ مسىدهـد. از اينرو، بررسى مناطقى كه در آن خطـر وقـوع زمسينلغـزش زيـاد است ضرورى بهنظر مىرسد. به اين منظور نياز بـه تكنيـكهـايى

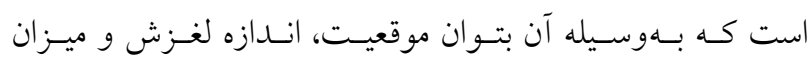

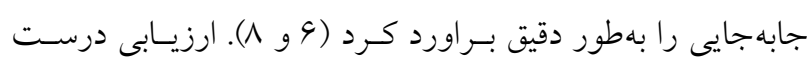
يديدهاى زئومورفولوزيكى نظير زمينلغزش، نيازمنـد بررسى و تحليل الكوى زمانى و مكانى جابه جايىهاست. نظـارت و يـايش ليش

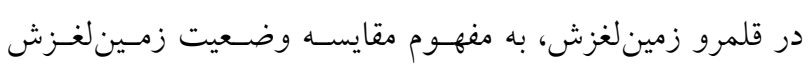
(مانند كسترش سـطحى، نـرخ حركـت، تويـو گرافى سـطحى يـا رطوبت خاك) در دورههاى مختلـف زمـانى، بـهـنظـور ارزيـابى

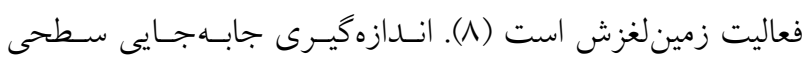

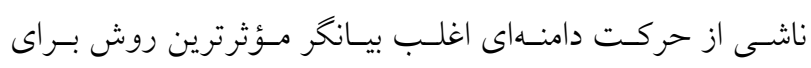
تعريف رفتار زمين لغزش بود كه مشاهده واكنش نسبت به عوامـل محرى و ارزيابى اثربخشى اقدامات كاهشى خطـر را امكـانيـذير

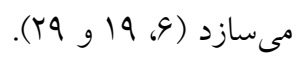
بازيابى جابه جايىهاى سطحى زمين با كذشت زمان، از نظر

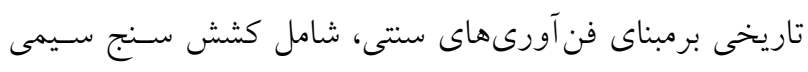

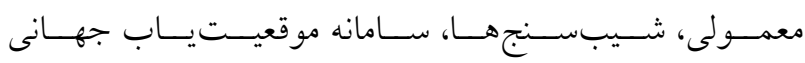
(GPS) (Global Position System) 
تاريخهاى اكتسابى مختلف را براساس تشخيص جابـهجـايى فـاز

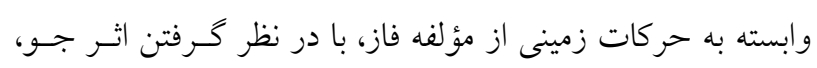

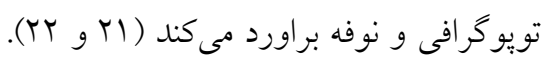

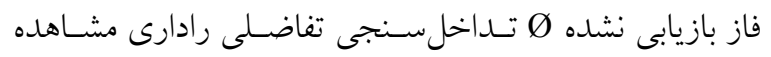

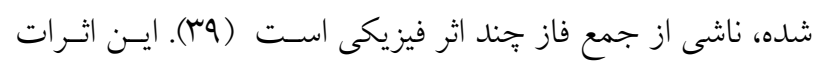

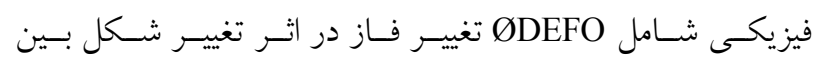

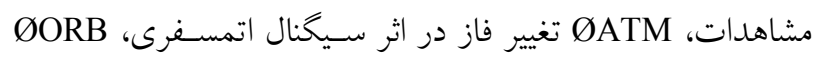

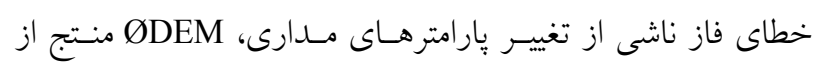

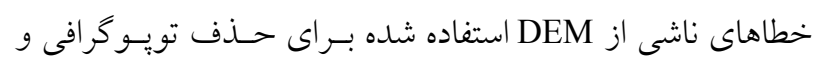

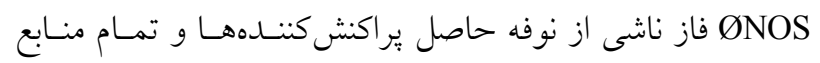

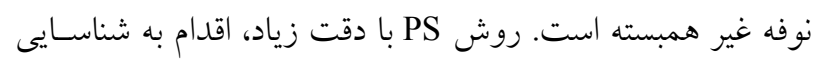

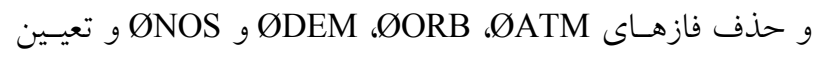

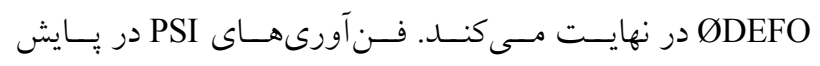

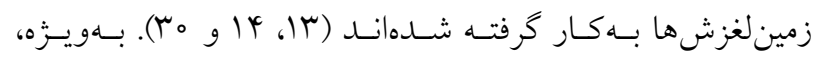

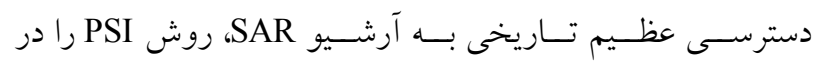

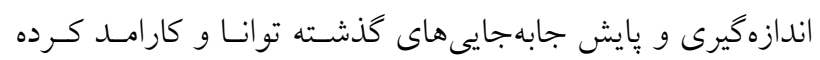

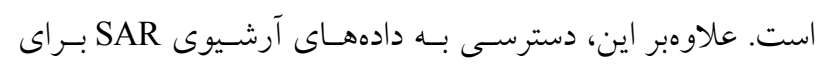

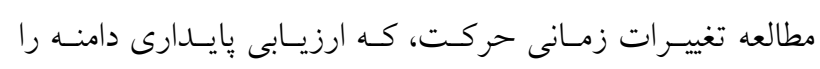

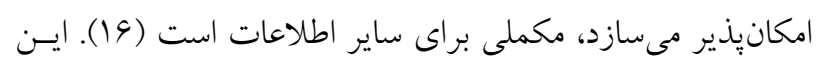

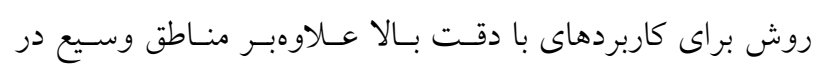

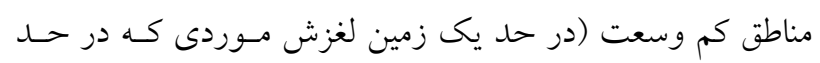

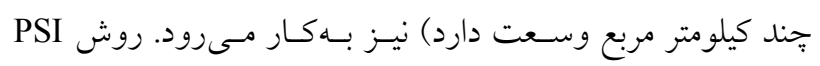

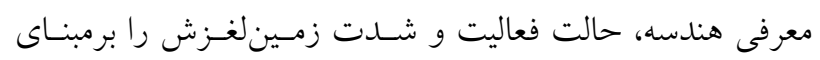

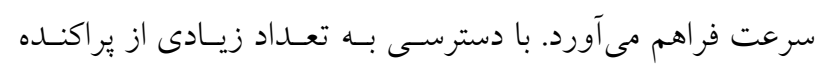

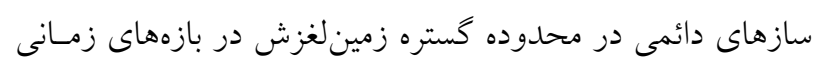

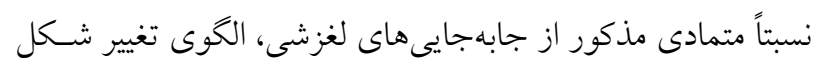

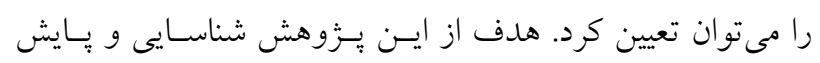

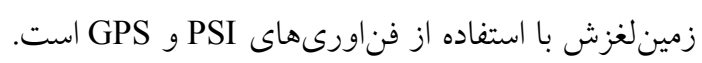

\section{مواد و روش منطقه مورد مطالعه} منطقه مورد مطالعه در شمال روستاى نقل از توابع دهستان پِادنا، منطه مورد
كاهش داد. استفاده بيش از دو تصوير رادارى سبب افزونكى در

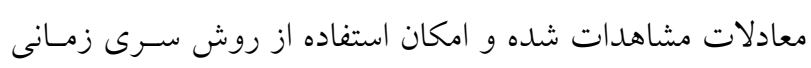
را مهيا مىسازد.

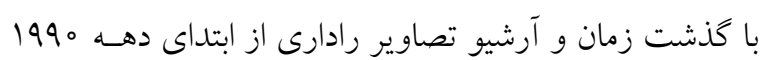

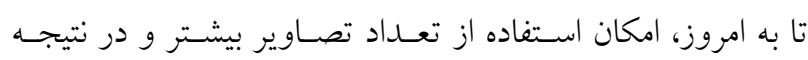

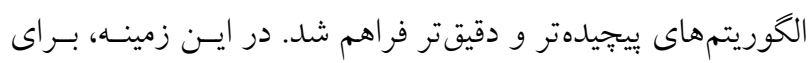

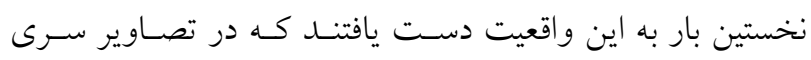

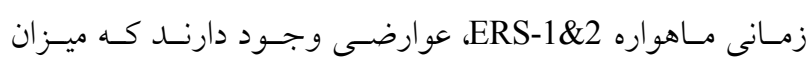

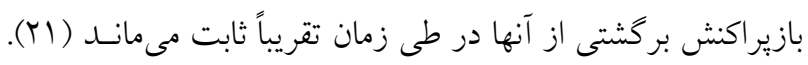

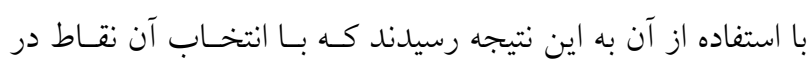

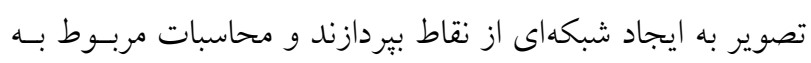

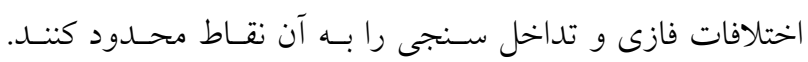

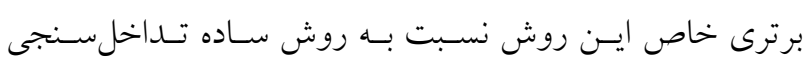

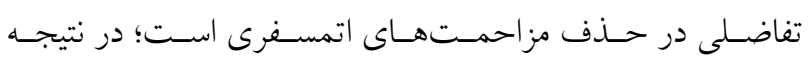

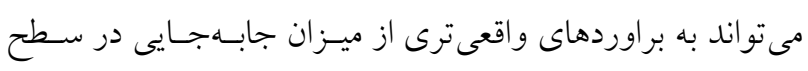
زمين دست يافت. اين روش بعدها مورد استفاده تعداد زيـادى از

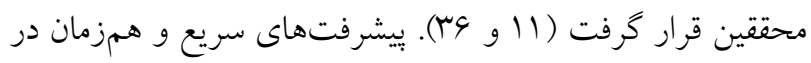

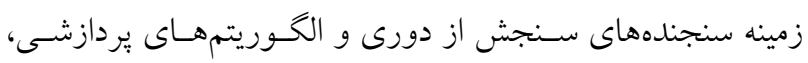

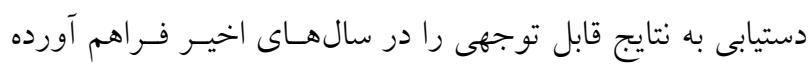

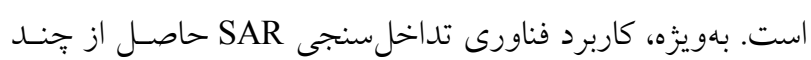

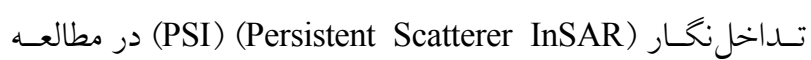

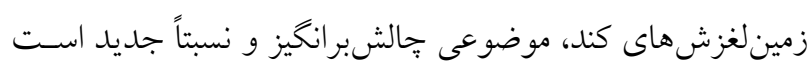

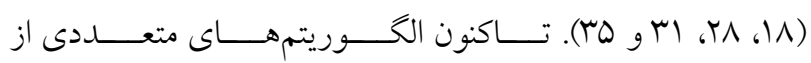

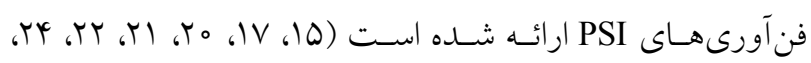

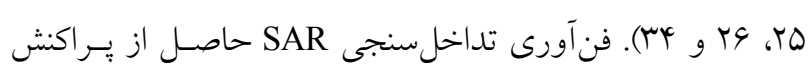

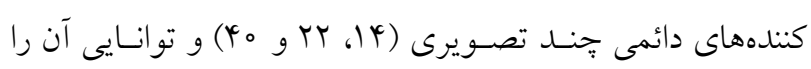

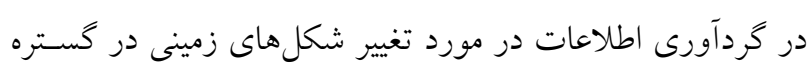

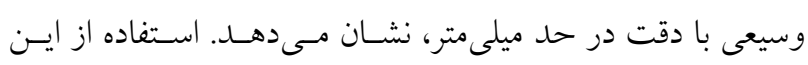

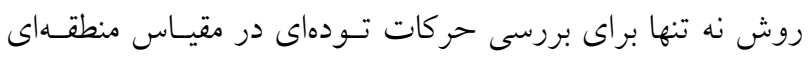

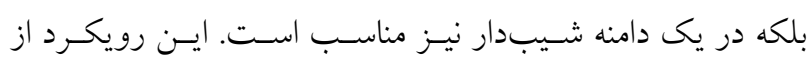

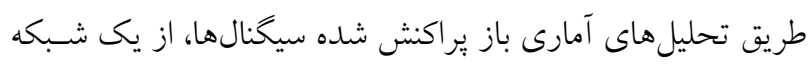

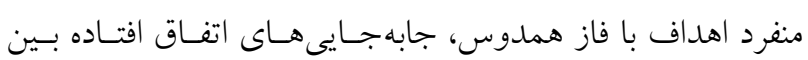




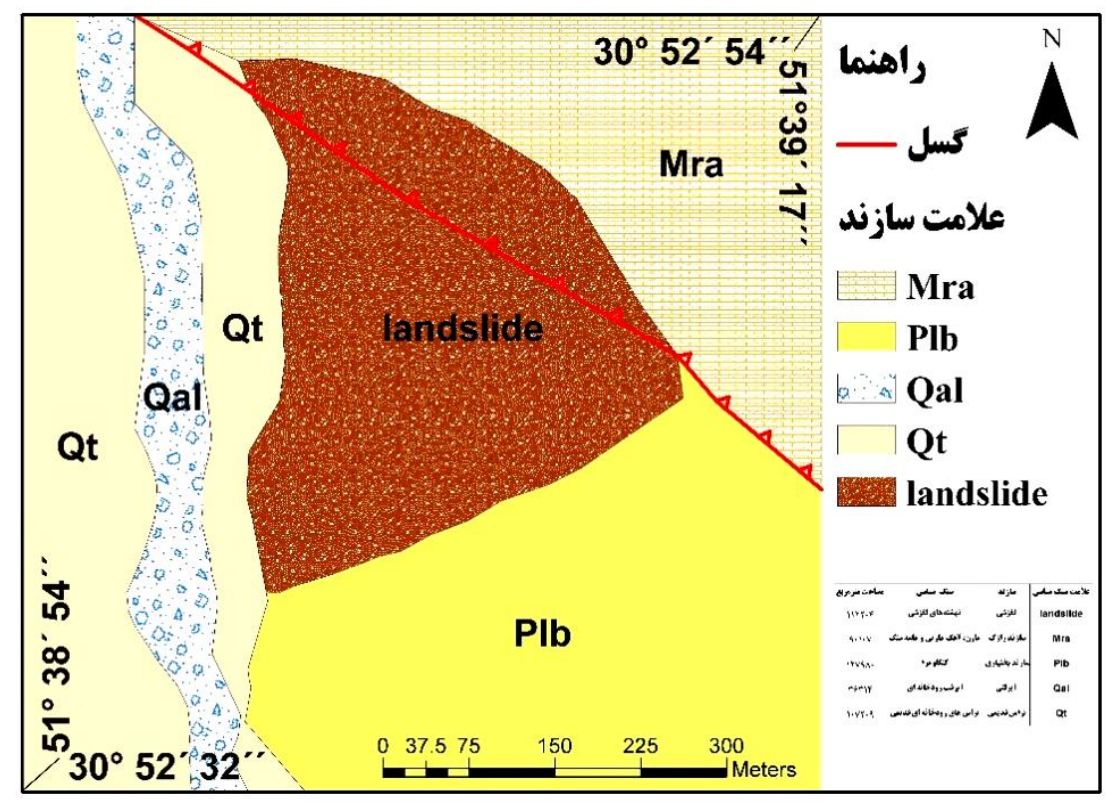

شكل 1. نقشه زمينشناسى محدوده زمينلغزش نقل

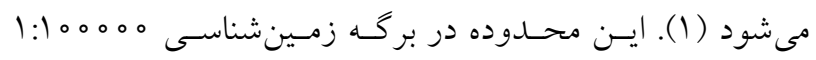

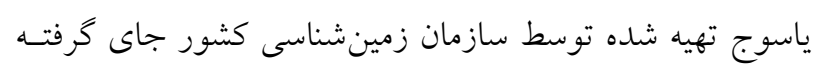

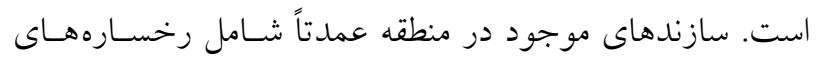

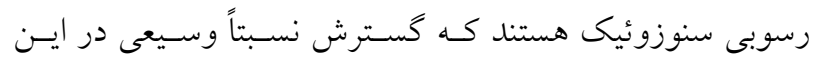

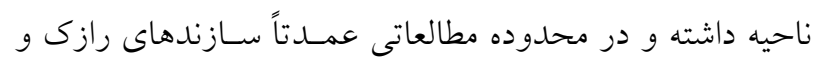
بختيارى و نهشتههاى كو اترنرى برونزد دارند. توده اصلى زمسين دهين

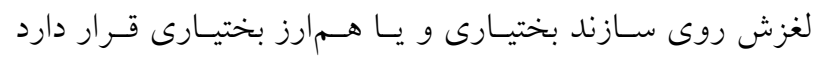

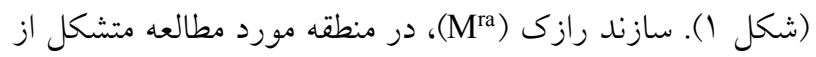

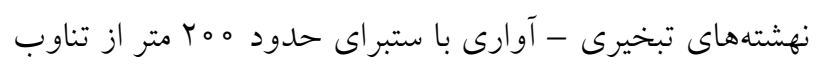

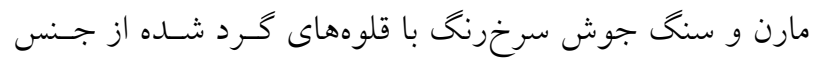

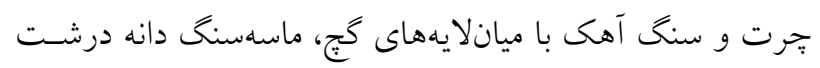

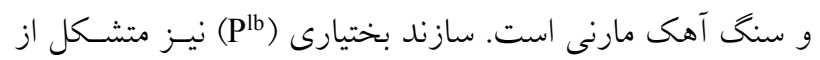

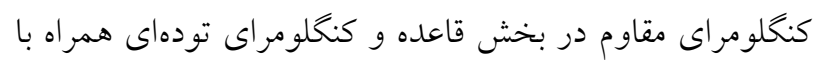

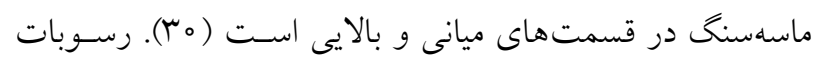

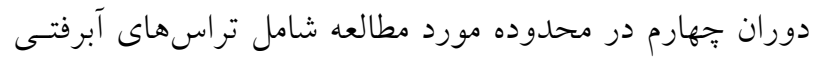

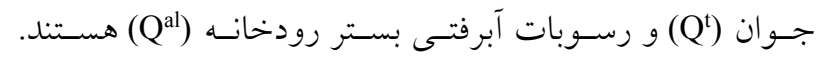

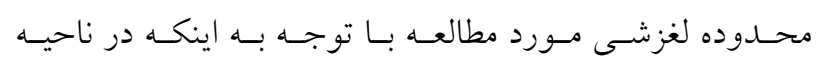

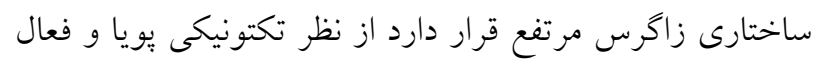

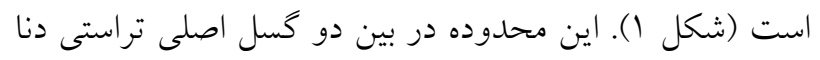

شهرستان سميرم واقع در ه م كيلومترى جنوب استان اصفهان

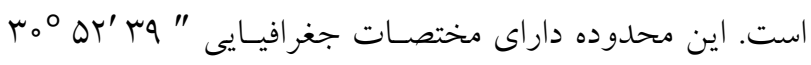

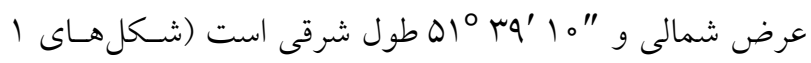
تا ץ). بهترين راه دسترسى به منطقه مورد مطالعه از طريق جـاده آسفالته سميرم - حنا - كيفته - نقل است. از نظر شرايط آبوهوايى، محدوده مورد مطالعه داراى رزيم

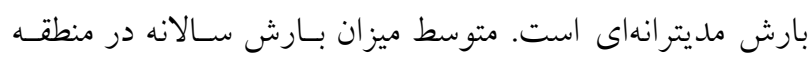

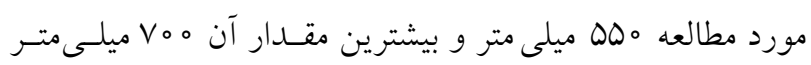

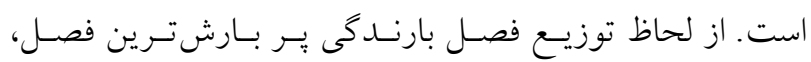

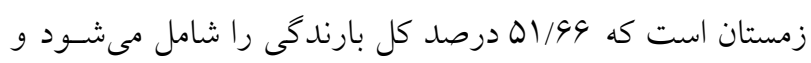

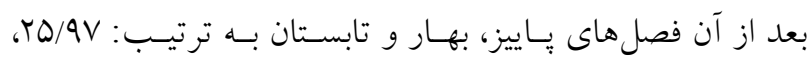

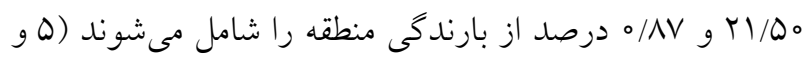

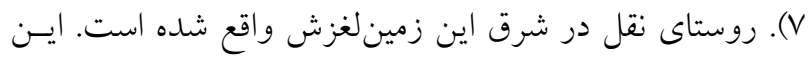

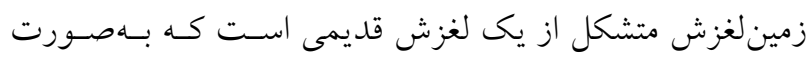
مركب در حال حاضر در قالب يكى لغـزش جرخشى در حسال

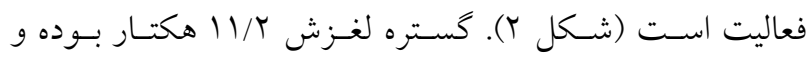
براساس طبقهبندىهاى رايج در طبقه آهسته تا خيلى آهسته قرار

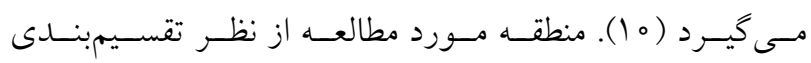

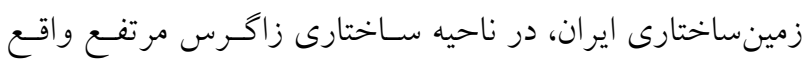




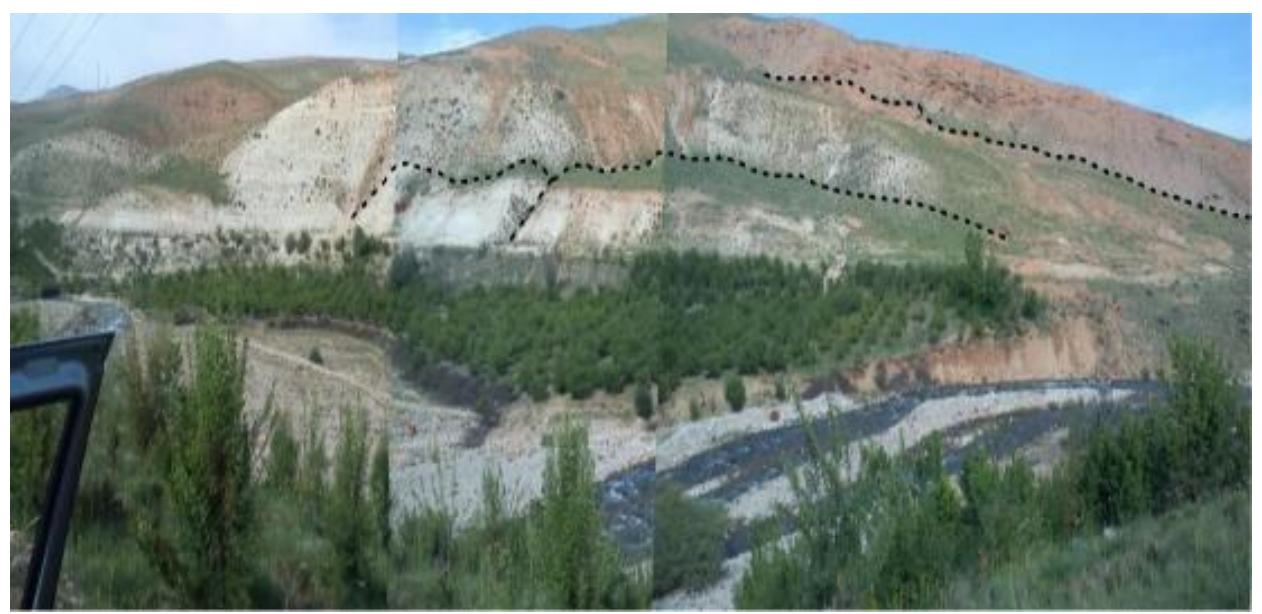

شكل r. نمايى از توده لغزشى نقل (نغاه به سمت شرق)

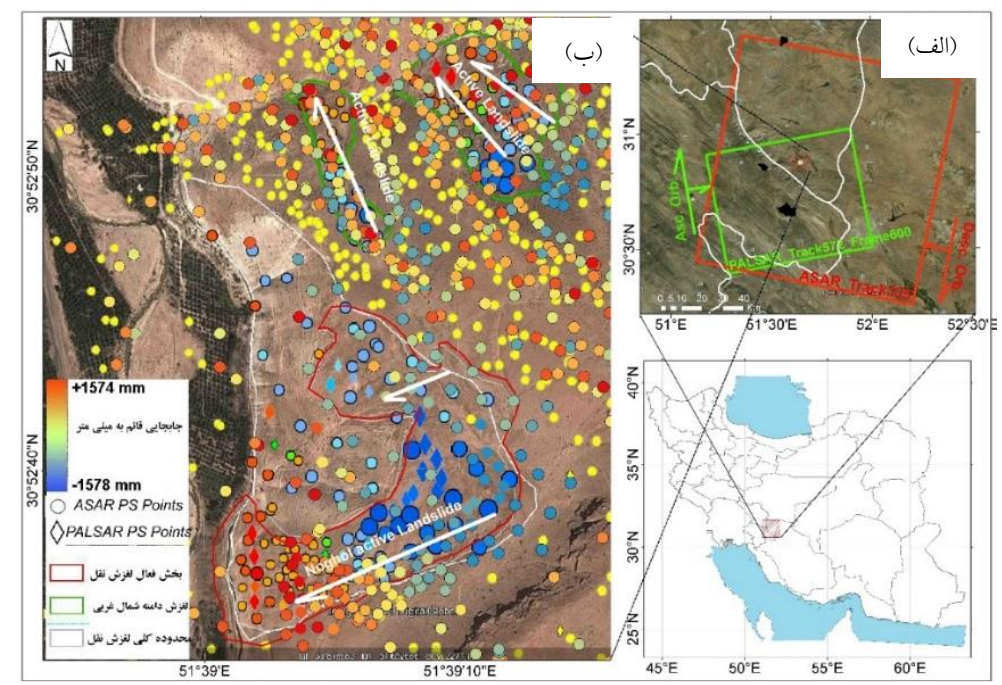

شكل r. موقعيت جغرافيايى زمينلغزش نقل الف) حالت مدارى تصاوير ASAR (كذريايين) و PALSAR (كذربالا) و موقعيت

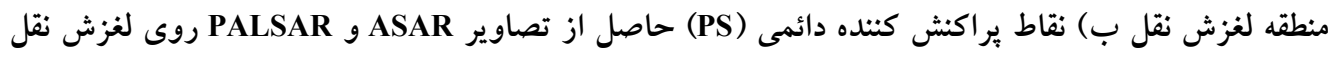

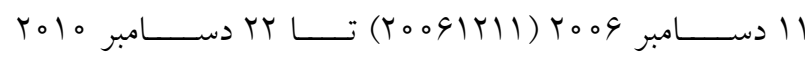

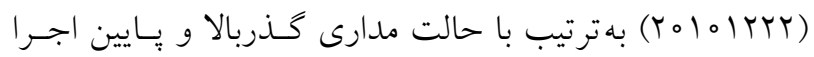
شده است. طول موج سنجنده ENVISAT (C تصويربردارى مجدد هب روز است. همجنين طول موج سنجنده ALOS-PALSAR

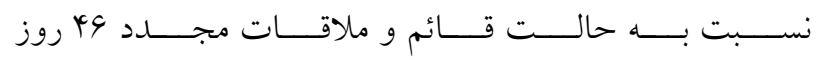

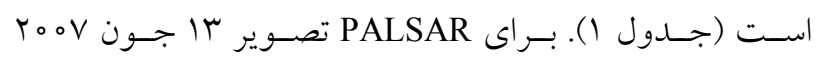

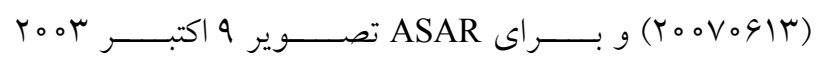

در جنوب غرب و كوه سياه در شمال شرق واقع است.

دادههاى مورد استفاده براى بررسى، شناسايى و يّايش زمينلغزش مورد مطالعـه، روش

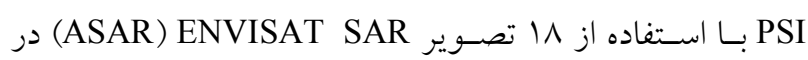

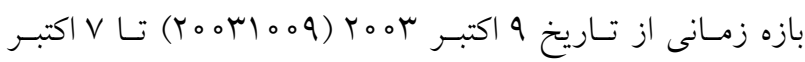

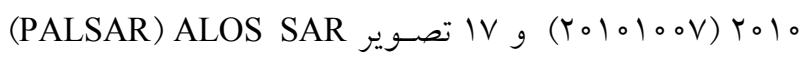
ور دو مـــــ FBS (Fine Beam Single polarization) FBD (Fine Beam Dual polarization) 
جدول ا. فهرست دادههاى رادارى مورد استفاده از سنجندههاى ASAR و PALSAR در روش PSI

\begin{tabular}{|c|c|c|c|c|c|c|c|c|}
\hline تصوير & $\begin{array}{l}1 \\
3 \\
3 \\
\frac{3}{3}\end{array}$ & عبور & مسير & قدرت تفكيك مكانى عمود بر & تفرت & زاويه فرود & تاريخ & $\begin{array}{l}3 \\
3 \\
3 \\
3 \\
3 \\
0\end{array}$ \\
\hline FBS & \multirow{17}{*}{ جִ } & \multirow{17}{*}{900} & \multirow{17}{*}{ DVY } & $V / 4 q$ & $r / \circ D$ & $r N / \vee q$ & Y००9/1T/1I & \multirow{17}{*}{ 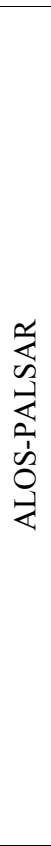 } \\
\hline FBD & & & & $14 / 91$ & $r / 00$ & $r N / V \circ r$ & ro०V/04/Ir & \\
\hline FBS & & & & $V / 4 q$ & $r / \circ D$ & $r \Lambda / v \circ r$ & $r \circ \circ V /|r /| r$ & \\
\hline FBS & & & & $V / 4 q$ & $r / \circ 0$ & ґ / / ०。 & $r \circ \circ N / r / l 0$ & \\
\hline FBD & & & & $14 / 91$ & $r / \circ D$ & rN/GNY & Y००N/०Y/M。 & \\
\hline FBD & & & & $14 / 91$ & $r / \circ 0$ & rN/991 & $r \circ \circ N / \circ 9 / 10$ & \\
\hline FBD & & & & $14 / 99$ & $r / \circ \Delta$ & rN/GVT & $r_{0} \circ / / 09 / 10$ & \\
\hline FBS & & & & $V / 4 q$ & $r / \circ \Delta$ & rN/VII & ro०N/IT/IG & \\
\hline FBD & & & & $14 / 91$ & $r / \circ \Delta$ & rN/9qr & $r \circ 09 / 09 / 11$ & \\
\hline FBD & & & & $14 / 99$ & $r / \circ \Delta$ & rN/qVQ & $r \circ \circ q / \circ q / 11$ & \\
\hline FBS & & & & $V / Y q$ & $r / \circ 0$ & $r N / v \circ q$ & $r \circ \circ q / 11 / \circ r$ & \\
\hline FBS & & & & $V / \uparrow q$ & $r / \circ \Delta$ & rN/VOY & $r 0 \circ q / 1 r / 19$ & \\
\hline FBS & & & & $V / T^{*} \Lambda$ & $r / \circ \Delta$ & rN/VIr & Y010/0 T/0 & \\
\hline FBS & & & & $V / \uparrow \wedge$ & $r / \circ \Delta$ & rN/VIV & $r 0|0 / 0 r / r|$ & \\
\hline FBD & & & & $14 / 99$ & $r / \circ \Delta$ & rN/GVG & $r 010 / 00 / 09$ & \\
\hline FBD & & & & $14 / 99$ & $r / \circ \Delta$ & rN/GVA & $r 010 / 11 / 09$ & \\
\hline FBS & & & & $V / 4 q$ & $r / \circ 0$ & rN/999 & $r 010 / 1 Y / Y r$ & \\
\hline & \multirow{17}{*}{$\begin{array}{l}? \\
3 \\
3 \\
3 \\
3 \\
3\end{array}$} & \multirow{17}{*}{ סדז } & \multirow{17}{*}{ rqva } & $19 / 19$ & $\varphi / 00$ & $T M / T r$ & $r \circ 0 r / 10 / 09$ & \multirow{17}{*}{ 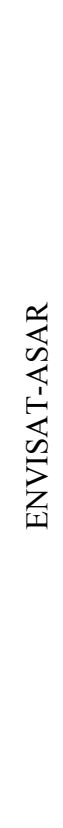 } \\
\hline & & & & $19 / v 9$ & $\varphi / 00$ & 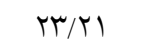 & $r \circ \circ r / 11 / 1 r$ & \\
\hline & & & & $19 / v 9$ & $\varphi / 00$ & $T M / T I$ & ro०r/IT/M & \\
\hline & & & & $19 / v 9$ & $\varphi / 00$ & TH/TY & roor/09/10 & \\
\hline & & & & $19 / v 9$ & $\varphi / \circ \Delta$ & $r \mu / T I$ & $Y \circ \circ Y / O V / I 0$ & \\
\hline & & & & $19 / v 9$ & $\varphi / 00$ & TH/Tr & roOr/ON/19 & \\
\hline & & & & $19 / 29$ & $\varphi / \circ 0$ & I & $r_{0} \circ Y / T \circ / T_{\Lambda}$ & \\
\hline & & & & $19 / v 9$ & $4 / 00$ & ח & $Y \circ \circ D / \circ D / Y G$ & \\
\hline & & & & $19 / v 9$ & $\varphi / 00$ & TH/Tr & $r \circ \circ \Delta / \circ N / \circ Y$ & \\
\hline & & & & $19 / v 9$ & $\varphi / \circ 0$ & Tr/Tr & $r \circ \circ \Delta / \circ q / \circ \Lambda$ & \\
\hline & & & & $19 / v 9$ & $\varphi / \circ \Delta$ & $T M / T I$ & Y009/0r/0Y & \\
\hline & & & & $19 / v 9$ & $\varphi / \circ \Delta$ & IT/YI & YO०V/II/TY & \\
\hline & & & & $19 / 19$ & $\varphi / 00$ & TH/Tr & $r \circ \circ N / \circ Q / 10$ & \\
\hline & & & & $19 / v 9$ & $4 / 00$ & TI/TI & $r \circ \circ q /|r / r|$ & \\
\hline & & & & $19 / v 9$ & $\varphi / \circ \Delta$ & TH/TY & $r_{0} 10 / 0 \% / 10$ & \\
\hline & & & & $19 / 29$ & $\varphi / 00$ & $r M / T l$ & $r_{0} / 0 / 00 / r_{0}$ & \\
\hline & & & & $19 / v 9$ & $\varphi / 00$ & $T M / T I$ & $Y 010 / 09 / T Y$ & \\
\hline
\end{tabular}

جهت ايجاد مجموعه (stack) تداخلسنجها در نظر گرفته شدند

(شكل هاى ثأ و ه). همجنين در طى مراحل اجراى روش PS از

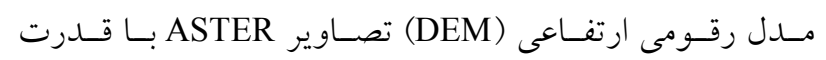

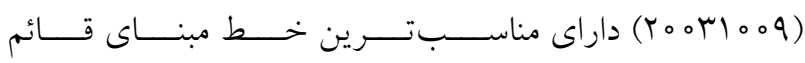

و همدوسى (Perpendicular baseline) به ديكر تصاوير هستند. لذا بـهنــوان تصـوير اصـلى (master) 


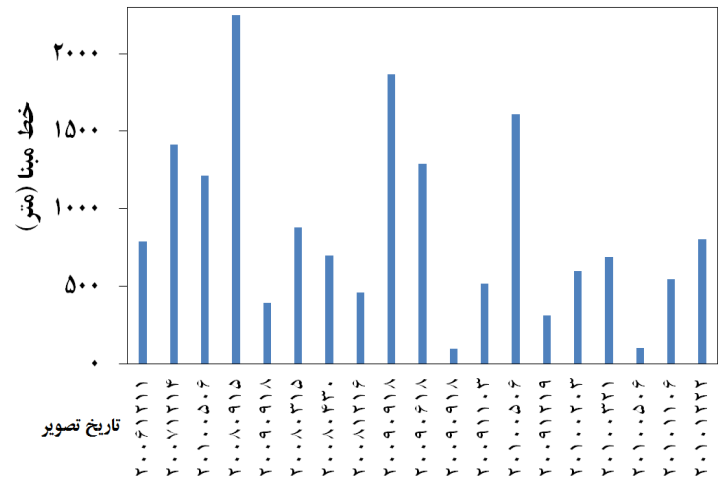

شكل ه. توزيع مقاديرخط مبناى دادههاى ENVISAT ASAR (حركت مدارى: كذريايين، كذر: هسז، زاويه فرود: سمت ديد: راست، قطبش: HH)

شده، حذف شد. منظـور از جابـهجـايى فـاز همـان ميـزان فـاز باقى مانده از مرحله واييجش فــاز اسـت كـه ناشسى از خطاهـاى مدارى، فاز حاصل از خطاى رمٍ است كه بايستى براى تبــيل فاز به ارتفاع يا جابهجايى زمين با استفاده از نقاط GCP تعريف شده با استفاده از يالايش و تسطيح مجـدد آن را تصحيح كـرد. محاسبه اين جابهجايى فـاز روى بيكسـل تصـوير، بـا بـالاترين

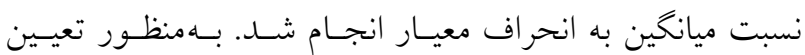

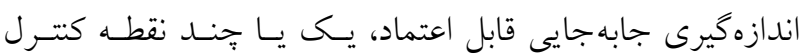
زمينى (GCP) در يردازش وارد شد. اين دادهها، ارزيسابى رونسـ

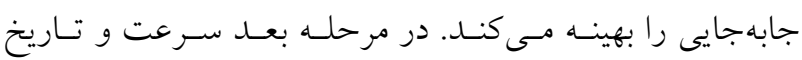

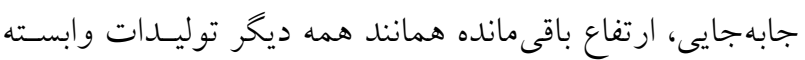

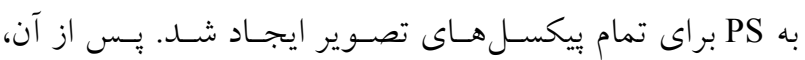

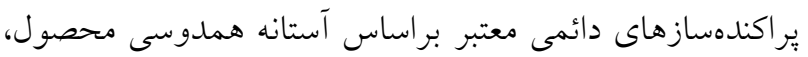

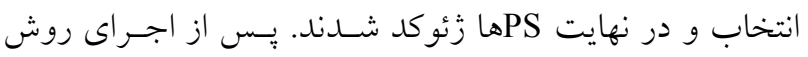

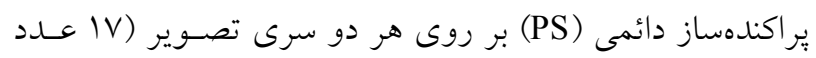

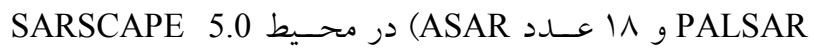
بهصورت مجزا براى هر يـــ از دو سـرى تصـوير، يـك فايـل نقطهاى (نقاط PS) بـا فرمـت رقـومى حاصـل شــــ اطلاعـات توصيفى اين فايلها حاوى ميزان جابهجايى كل، سرعت يا نـرخ

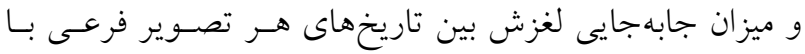
تصوير اصلى در طول دوره زمانى تصاوير مورد استفاده اسـت.

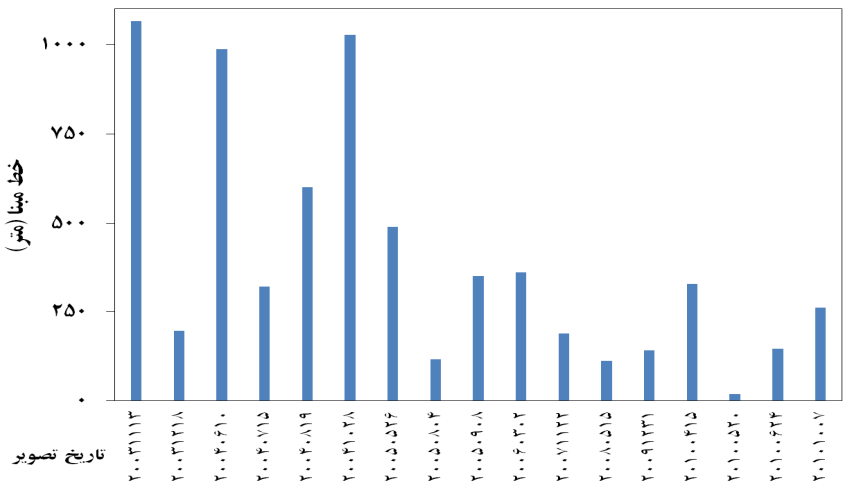

ALOS PALSAR شكل f. توزيع مقاديرخط مبناى دادههاى (حركت مدارى: گذربالا، كذر: OVY، عبور:900،

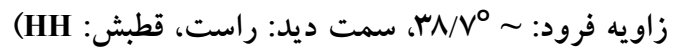

تفكيك مكانى يك ثانيهاى و دقت ارتفاعى حدود مب متر بـراى

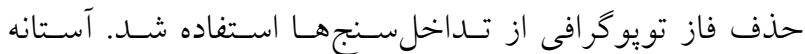

همدوستى نيز در حين اجراى روش، لVDه در نظر كرفته شد. بهمنظور اجراى روش PS از نرمافزار SARSCAPE 5.0 بـر

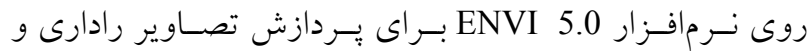

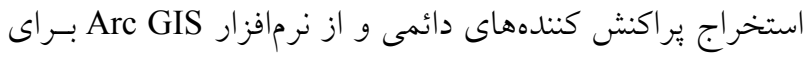
بررسى، تحليل و مدلسازى دادههاى حاصل از يردازش تصاوير در محيط 5.0 ENVI استفاده شد.

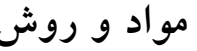

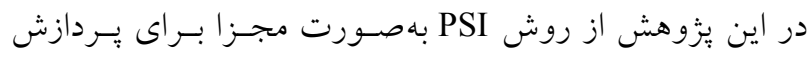

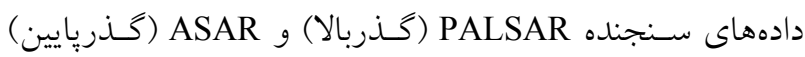

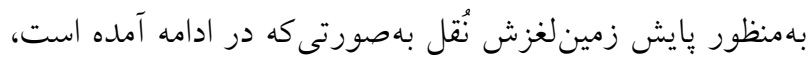

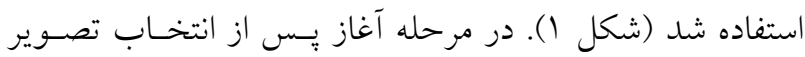

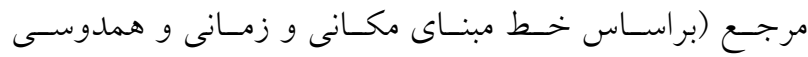
مناسب)، همه تصاوير نسبت به فايـل مرجـع بـه ثبـت رسـانده شدند. در مرحله بعدى جفتهاى تداخلنشار نسبت به تصـوير

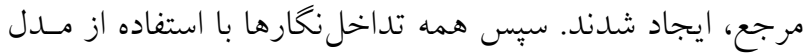
رقومى ارتفاعى (DEM) حاصـل از يـردازش تصـاوير ASTER تصوير شده روى هندسه برد مايل تصوير اصلى، تسطيح شدند.

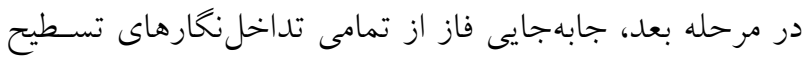


لغزش نزديك باشد و شرط سوم، خط مبناى قائم كوجـك، اثـر

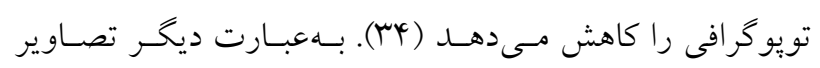

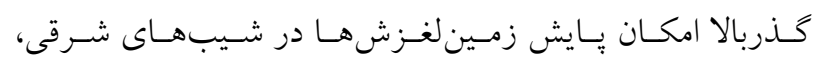

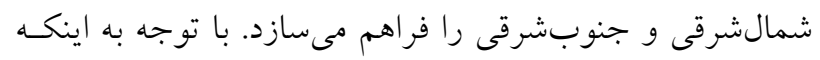

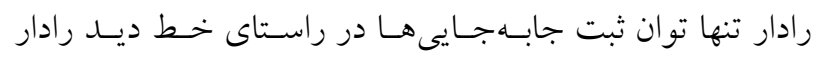

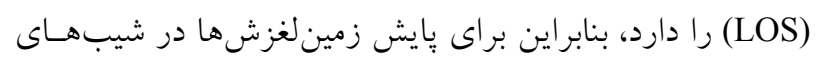

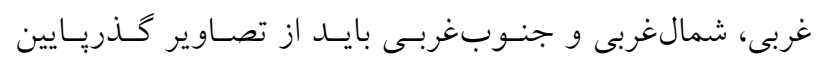

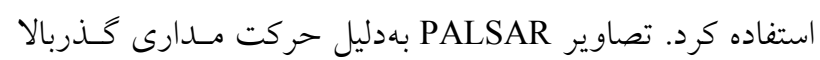
داراى خط ديد (LOS) به سمت شرق است، بنابراين لغزش هاى

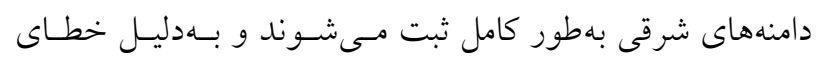

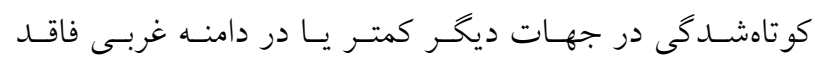

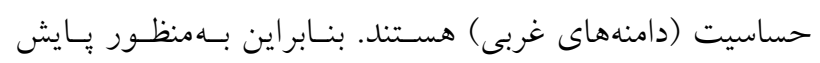

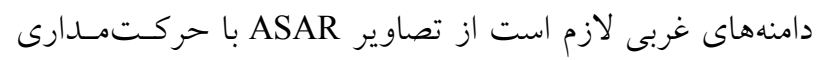

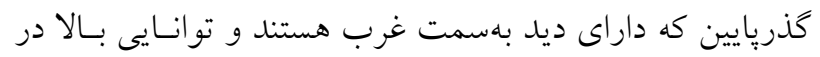

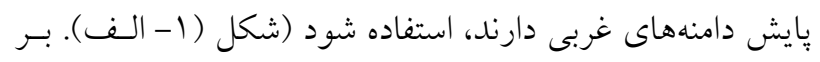

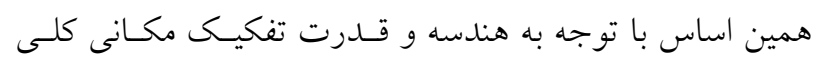

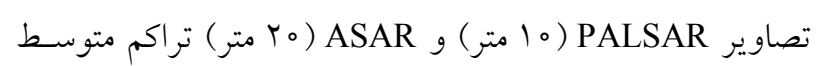

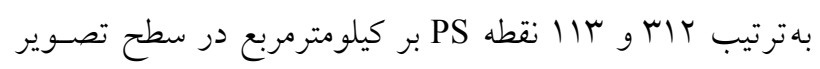

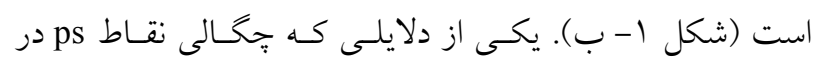

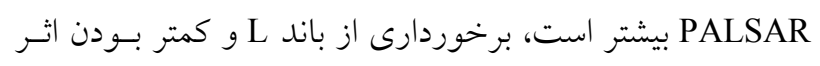

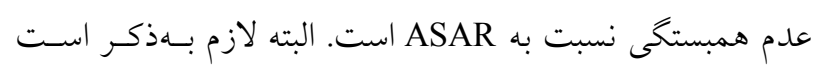

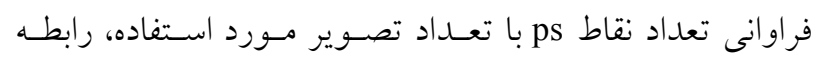

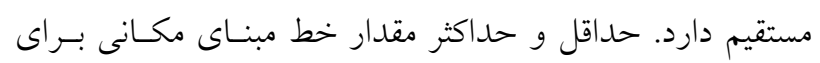

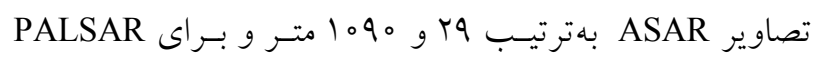

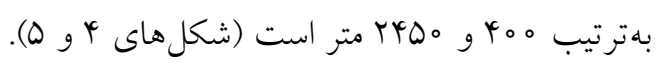

\section{ارزيابى و تفسير نتايج PSI و پايش زمينلغزش}

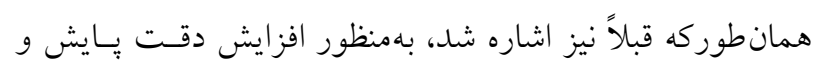

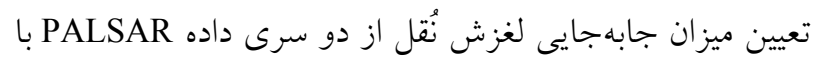

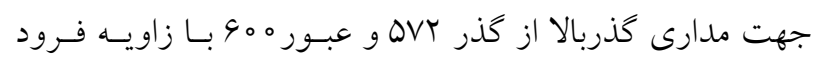
r MN/ درجه و سمت ديد راست با قطبش افقى - افقى از تساريخ

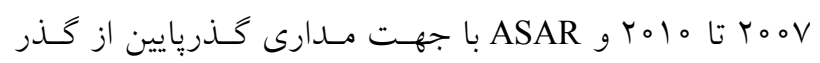

بهنظور مقايسـه بهتـر نتسايج PS تصـاوير PALSAR و ASAR

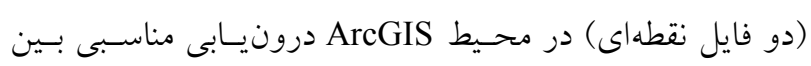

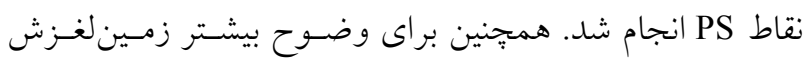

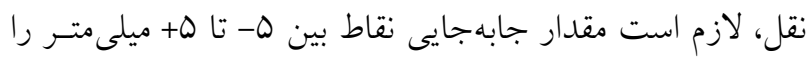

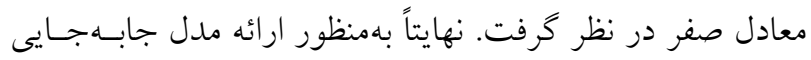

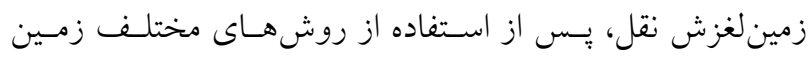

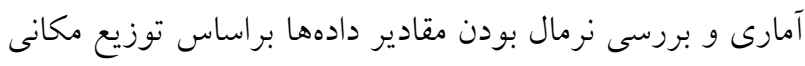

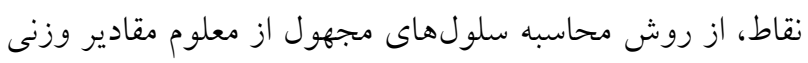

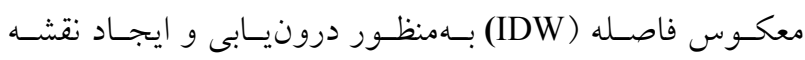

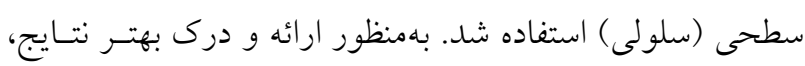

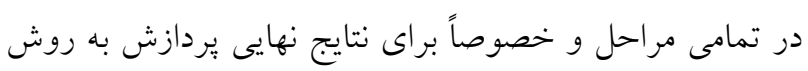
PS هميوشانى و تلفيقى استفاده شدند.

نتايج و بحث

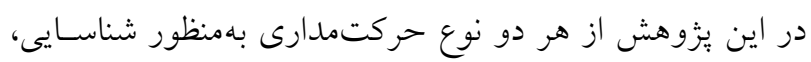

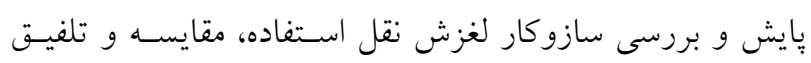

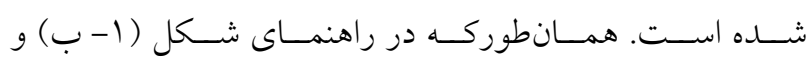

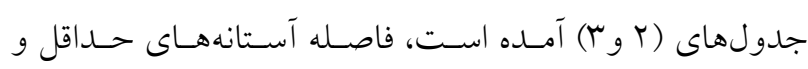

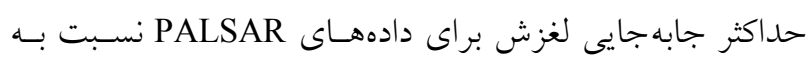

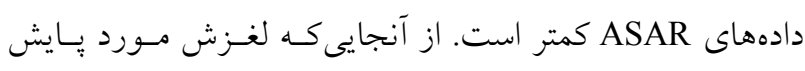

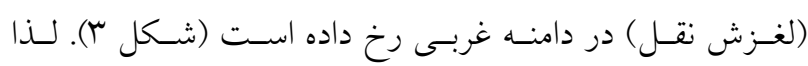

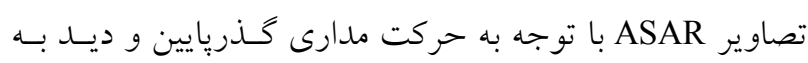

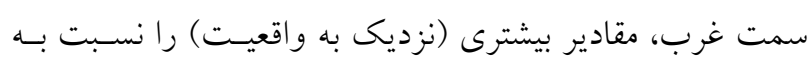

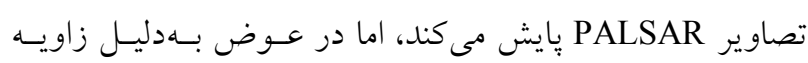

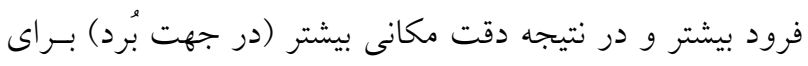

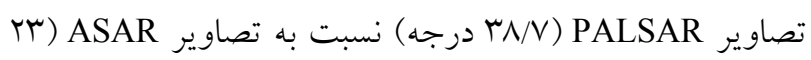

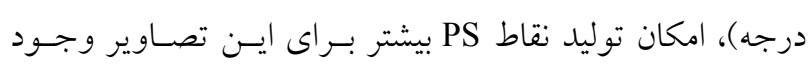

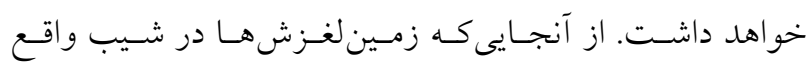

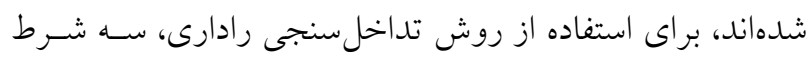

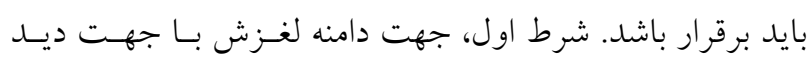

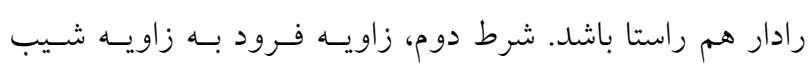


شناسايى، بايش و بررسى ساز و كار زمينلغزش با استفاده از روش....

جدول Y. ميزان جابه جايى برحسب ميلىمتر در نواحى مختلف زمينلغزش نقل براساس دادهاى PALSAR از צ०

\begin{tabular}{|c|c|c|c|c|c|}
\hline اختلاف & جمع & ميانخين & تخليه & انباشتكى & تاريخ تصوير \\
\hline$\circ$ & $\circ$ & $\circ$ & $\circ$ & $\circ$ & D_Y००9|YाI \\
\hline lra & ror & $-V$ & -99 & 90 & $D_{-} r_{\circ} \circ V \circ G \mid r$ \\
\hline ITO & rmq & -9 & س & Gr & $D_{-} Y \circ \circ V|r| Y$ \\
\hline IOV & ras & 。 & $-\lambda k$ & $v^{4}$ & D_r०० \\
\hline let & TYY & -0 & $-\Delta \wedge$ & $\Delta r$ & 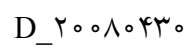 \\
\hline 111 & TSI & $-\phi$ & س & Q. & $D_{-} Y \circ \circ \Lambda \circ 910$ \\
\hline 1ra & Mlt & -10 & $-V Q$ & 91 & D_ro० \\
\hline 100 & $r \circ r$ & $-r$ & $-V \wedge$ & WV & D_r००NIr|G \\
\hline T19 & per & $-1 r$ & $-1 \circ 1$ & 101 & $D_{-} Y_{0} \circ 9.911$ \\
\hline rlo & سחק & -4 & $-9 V$ & 111 & $D_{-} r_{0} \circ 90911$ \\
\hline TIT & pqy & - & $-9 r$ & Iro & $D_{-} r \circ \circ 911 \circ r$ \\
\hline סמז & $\forall \varphi \wedge$ & $-V$ & -119 & 119 & $D_{-} r \circ \circ 91 r 19$ \\
\hline$r \circ r$ & $49 \Lambda$ & -9 & $-1 \circ 4$ & 99 & D_r०|००Y०r \\
\hline TrA & س & $-\wedge$ & -100 & IrA & D_ro|००Kr \\
\hline TYY & ka9 & $-\Lambda$ & -99 & IrA & $D_{-} r_{0} 1000 \cdot 9$ \\
\hline TrI & ט & -11 & -110 & 111 & $D_{-} Y_{0} 101109$ \\
\hline TH & $\Delta D G$ & $-r$ & -109 & IrT & D_Y0101KYT \\
\hline TYl。 & $-\Lambda V Y G$ & -110 & $-I T \circ V$ & $I r \circ r$ & جابهجايى كل \\
\hline 49 & $-Y \mid Y I$ & - & $-T^{4}$ & r & نرخ جابه جايى \\
\hline
\end{tabular}

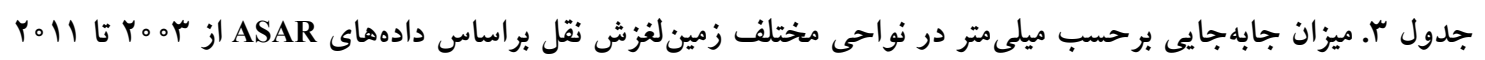

\begin{tabular}{|c|c|c|c|c|c|}
\hline اختلاف & جمع & ميانخين & تخليه & انباشتخى & تاريخ تصوير \\
\hline$\circ$ & $\circ$ & $\circ$ & $\circ$ & $\circ$ & D_r०० Tl००Q \\
\hline TV & $\Delta r$ & $-\circ, V$ & -14 & Ir & D_ro० \\
\hline سr & $\Delta r$ & $-\circ, \uparrow$ & -10 & IV & D_ro०rIrIA \\
\hline kq & VT & $-\circ, V$ & $-M Y$ & rQ & $D_{-} Y \circ \circ Y \circ V I O$ \\
\hline kV & gr & $\circ, r$ & $-r T$ & ro & $D_{-} Y_{0} \circ \varphi_{0} 910$ \\
\hline$\Delta \wedge$ & $9 \Lambda$ & $\circ, t^{r}$ & $-r q$ & $\mu_{0}$ & $D_{-} Y_{0} \circ Y_{0} \wedge 19$ \\
\hline 91 & $\Lambda$ & $-\circ, r$ & $-r q$ & Tr & $D_{-} Y \circ \circ Y I \circ Y \Lambda$ \\
\hline ^。 & 99 & $-\circ, V$ & $-4 \mid$ & $\varphi_{0}$ & $D_{-} r \circ \circ \Delta \circ \Delta r \varphi$ \\
\hline$\wedge 9$ & 100 & $-0, r$ & $-k T$ & ky & $D_{-} Y \circ \circ \Delta \circ \Lambda \circ Y$ \\
\hline r & 110 & $-\circ, V$ & $-\psi \wedge$ & id & $D_{-} r \circ \circ \Delta \circ q^{\prime} \wedge \Lambda$ \\
\hline $11 r$ & D & $-1, r$ & $-\Delta \Delta$ & $\Delta V$ & $D_{-} Y_{0} \circ 9 \circ r_{0}$ \\
\hline IV & YYI & -4 & $-9 r$ & ᄉ。 & $D_{-} r_{0} \circ V \| Y r$ \\
\hline 199 & TSV & $-\varphi, V$ & $-\wedge 9$ & $\Lambda r$ & $D_{-} Y \circ \circ \Lambda \circ \Delta \mid Q$ \\
\hline rrv & rVt & $-9,9$ & $-1 Y \Lambda$ & 109 & D_ \\
\hline req & mag & $-v, r$ & - & 114 & $D_{-} Y_{0} 100410$ \\
\hline YYA & rqv & $-v, q$ & - & 119 & $D_{-} Y_{0} 100 \Delta Y_{0}$ \\
\hline r & $\varphi 01$ & $-Q, \wedge$ & $-|\psi|$ & $|r|$ & D_Y01009YY \\
\hline TAY & pro & $-V$ & $-1 k r$ & 140 & $D_{-} Y 010100 \mathrm{~V}$ \\
\hline$r \circ \Delta l$ & VTr & $-1 \Delta \Delta, r$ & $-10 V Y^{c}$ & IKVV & جابهجايى كل \\
\hline kq & 140 & -r,r & $-T_{G}$ & r & نرخ جابهجايى \\
\hline
\end{tabular}


كه با كذشت زمان تقريباً ميـزان حجـم تخليـه بـا انباشـتخى در

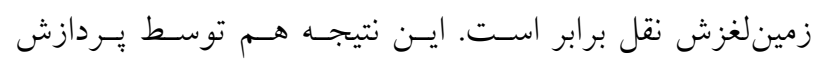

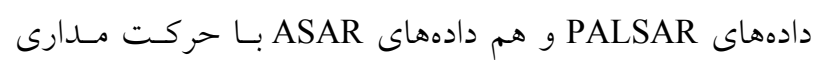

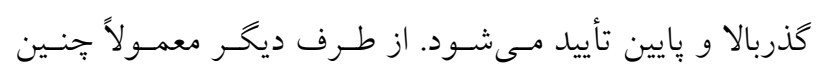

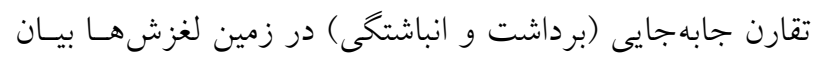

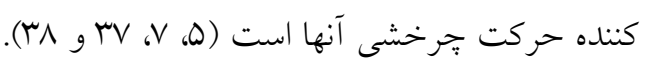

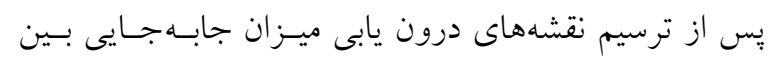

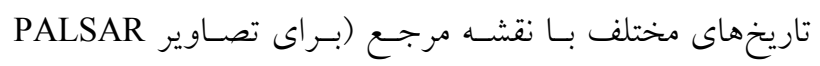

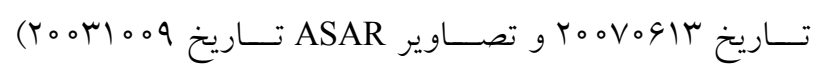
زمينلغزش نقل بهخوبى در تصاوير مشخص شـا (اشـكال ^و و

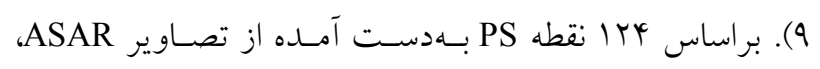

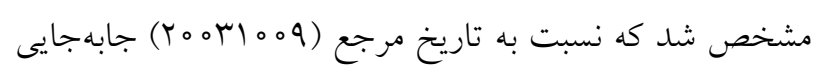
زمين لغزش در سه مرحله خلاصه مىشود:

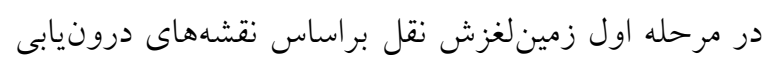

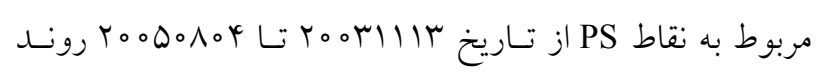

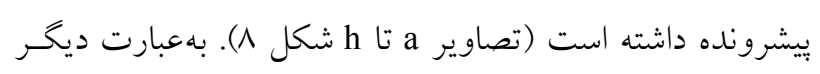

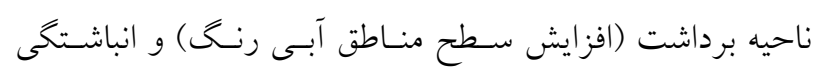

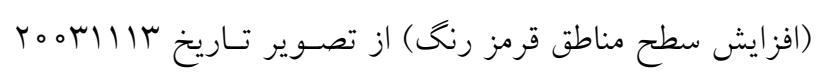

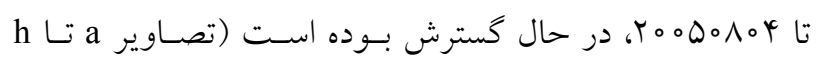

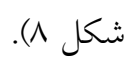

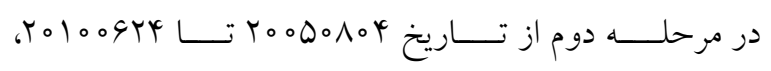

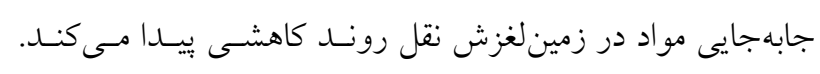

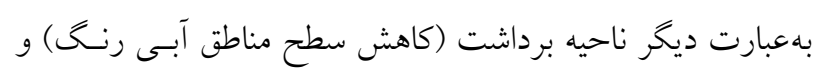

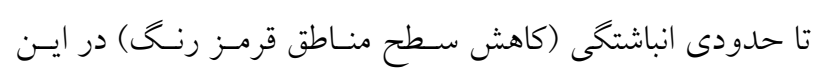

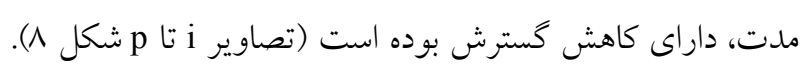

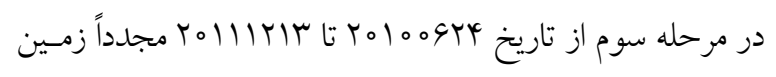

لغزش نقل روند بيشرونده بيدا كرده است (تصاوير p و q شكل ه م).

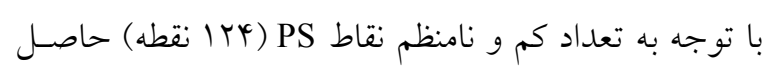
از تصـاوير ASAR، يــايش تغيــرات بـين ناحيـهـ برداشـت و

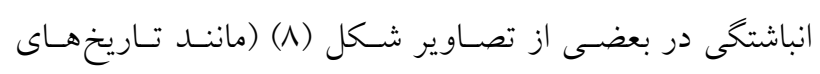
ه مىتواند برخوردار باشد (تصاوير d، k و n شكل ^).

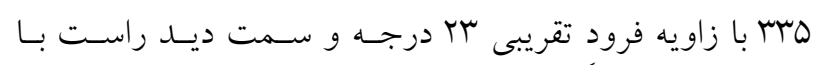

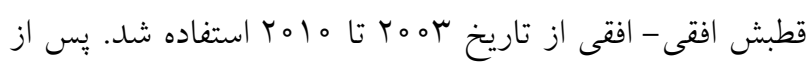

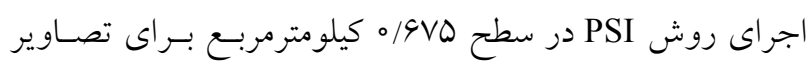

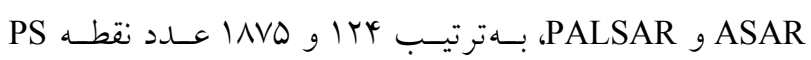

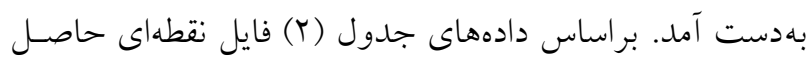

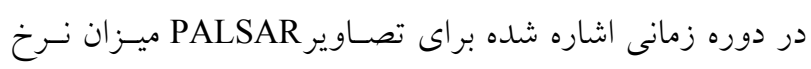

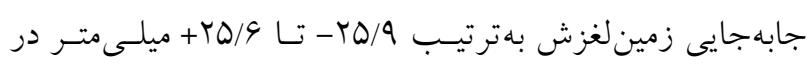

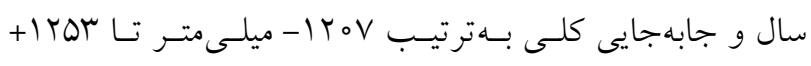

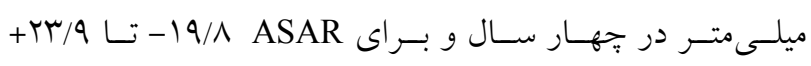

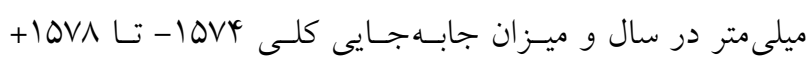

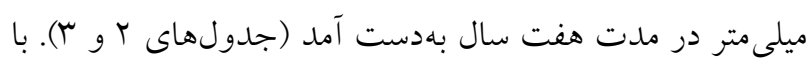

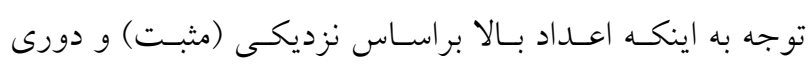

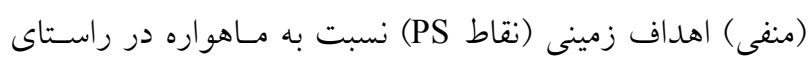

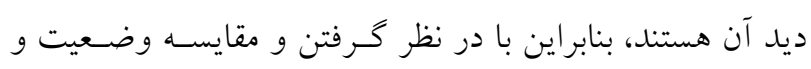

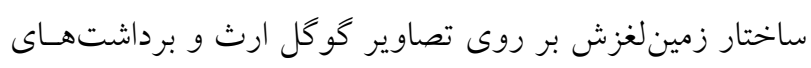

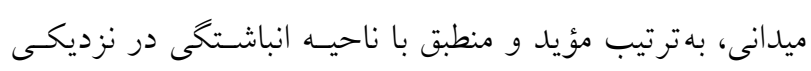

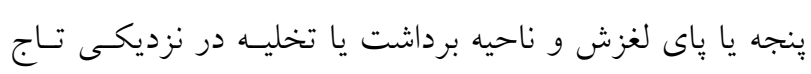

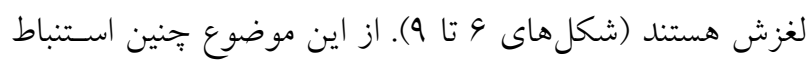

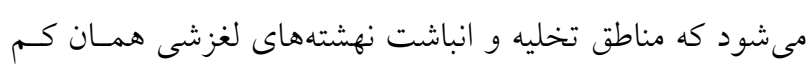
ارتفاع شدن (كودشدن) و مرتفع شدن (بالآمدكى) سطح زمسين

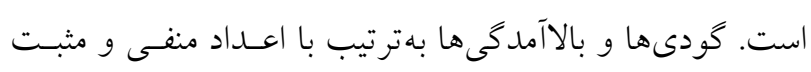

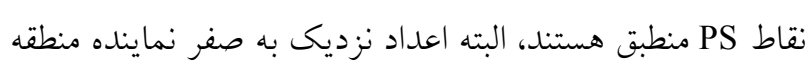

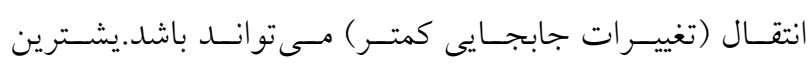

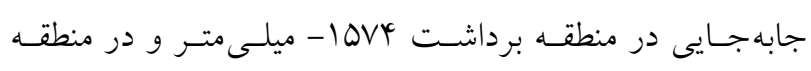

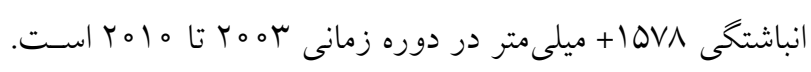

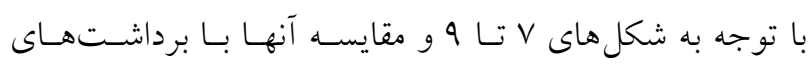

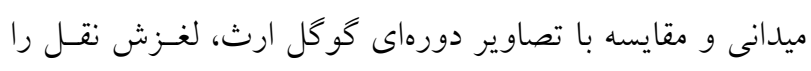

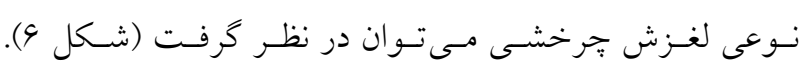

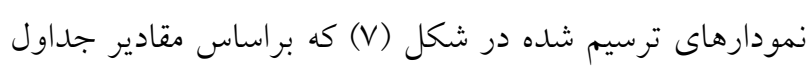

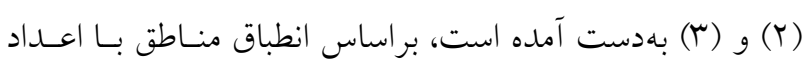

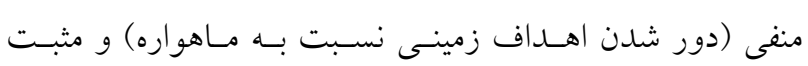

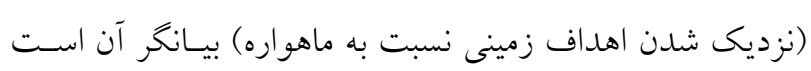




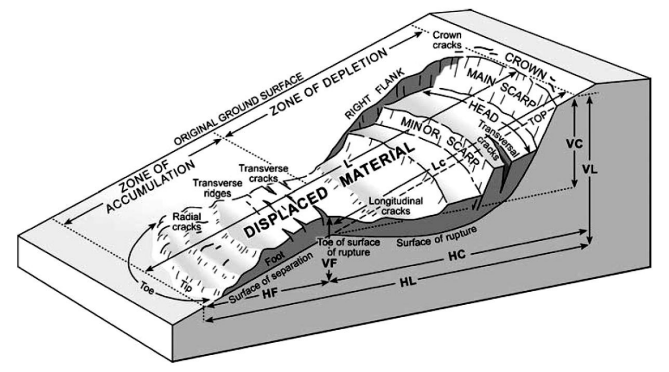

شكل 9. اجزاى زمينلغزش و بخشهاى تخليه و انباشت (rV و و
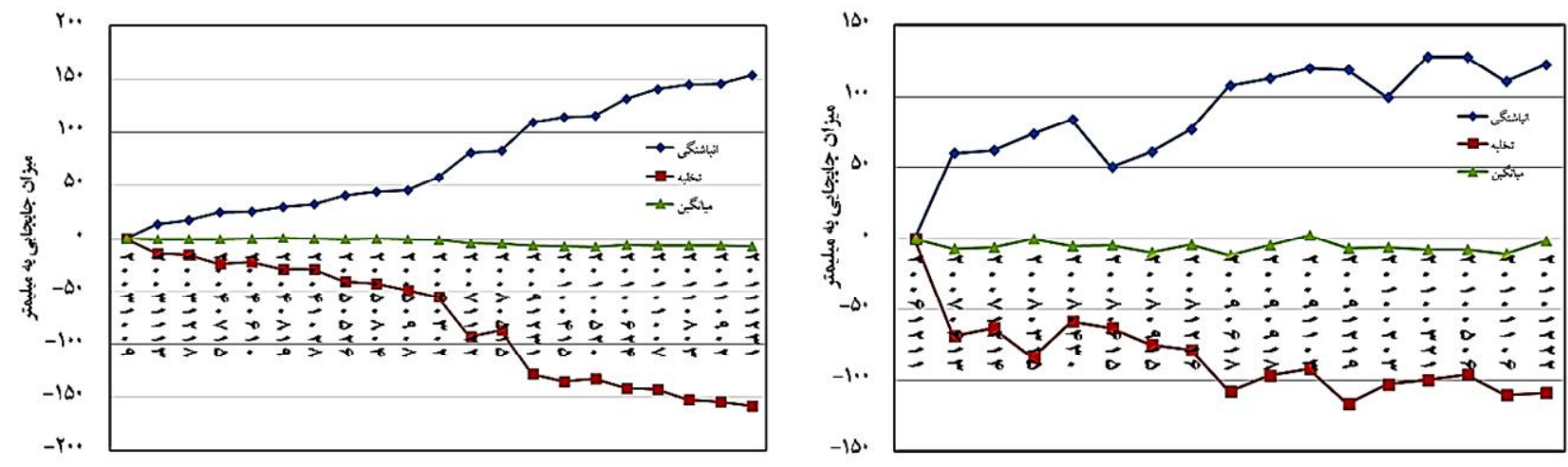

شكل V. نمودار ميزان جابهجايى در نواحى انباشت و تخليه زمينلغزش نقل براساس روش PS، الف) دادههاى PALSAR و ب) دادههاى ASAR

جابهجايى قائم و افقى سطح لغـزش يـا منطقـه لغزشسى اسـت.

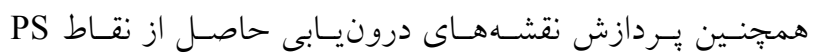
تصاوير ASAR، حاكى از وجود دو لغزش فعال در دامنه شـمال غربى است كه بهخوبى تشخيص داده شده است (شكل ^) و در تصاوير يردازش حاصل از PALSAR، به وضوح ديده نمىشود. در اين دو لغزش، دو ناحيه برداشت و انباشتگى به وضوح قابـل

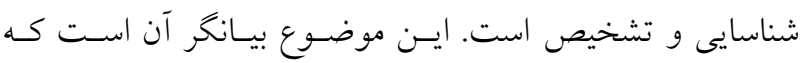
تصاوير ASAR در شناسايى لغزشهاى دامنـه شـمالغربسى نيـز بهتر از تصاوير PALSAR كارايى دارند.

بهوركلى با توجه به هندسـه مختلـف تصـاوير PALSAR

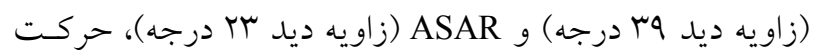
مدارى بهترتيب كذربالا و هايين اين دو سنجنده، موقعيت نقـاط PS حقيقت نزديك يا دور شدن نقاط PS را نسبت به سنجنده نشان
همجينين تصاوير PALSAR مطـابق مراحسل بردازشسى تصـاوير

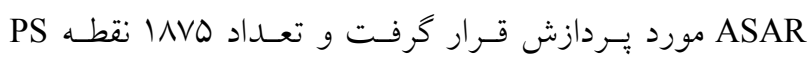
بهدست آمد كه در محيط ArcGIS نيز اقدام بـه درونيـابى آنهـا شد. با توجه به تعلداد بيشتر نقاط PS نسبت به تصساوير ASAR بهدليل دقت مكانى بيشتر و شرايط هندسـه ايسن نـوع تصـاوير،

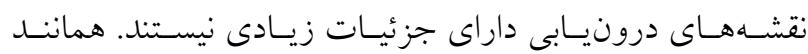
تصاوير ASAR روند تغييرات جابهجايى در نقشههاى حاصل از يردازش تصاوير PALSAR تا حدودى داراى دو مرحلـه رونـــ

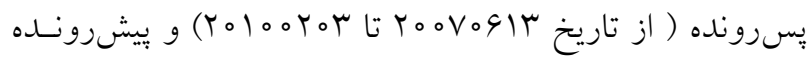

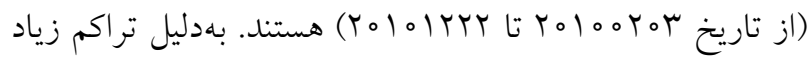
نقاط PS، درونيابى نقاط PS جزئيات بيشترى را نشان مىدهنـد (شكل 9). ولى همانطوركه در شكل (N) نيز نمـايش داده شـده اسـت، تصـاوير ASAR بـهدليـل حركـت مــارى كـذريايين و راستاى ديد مناسب، داراى نقاط PS، نماينـده دقيـقتـرى بـراى 

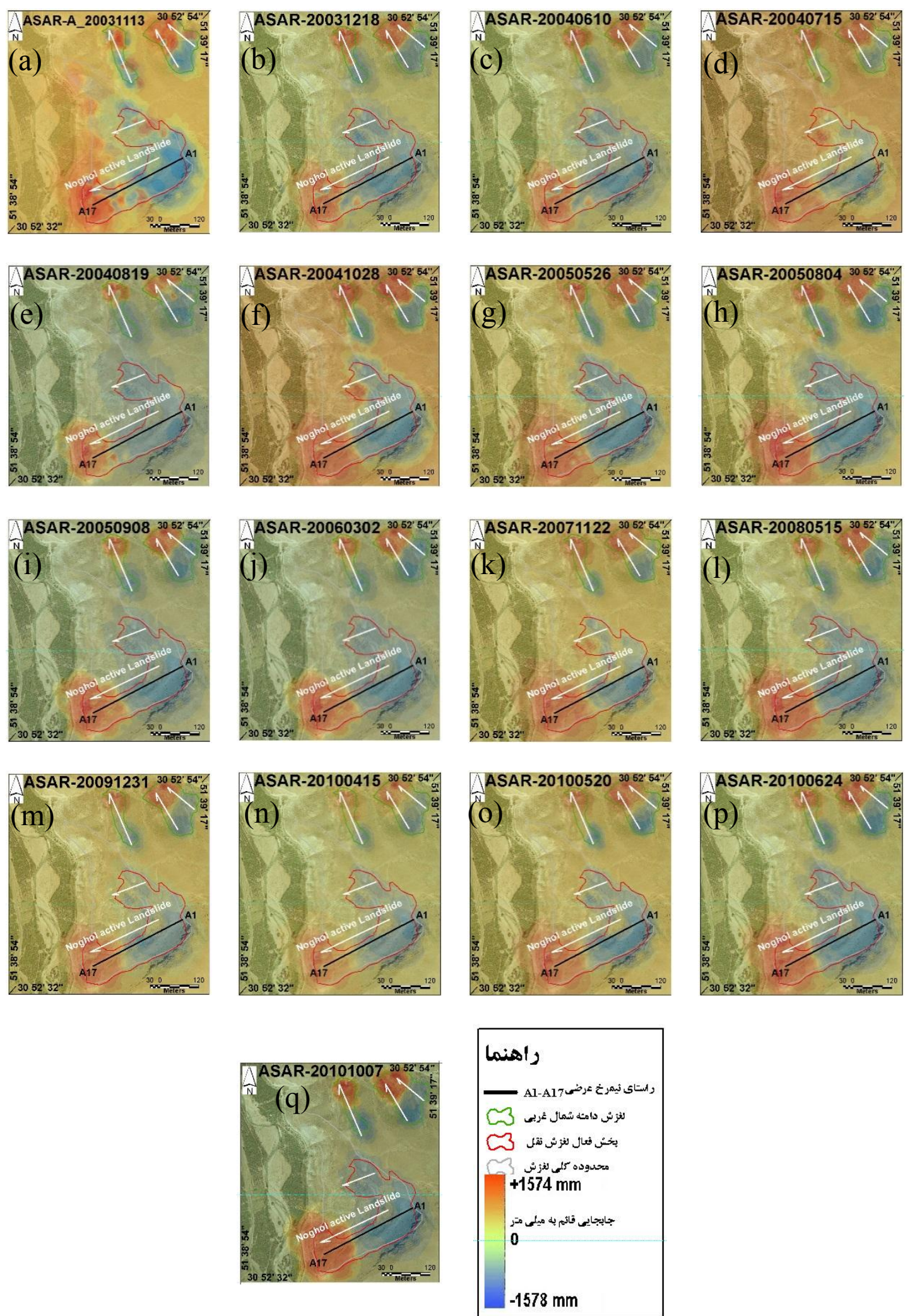

شكل ^م نقشههاى درونيابى حاصل از نقاط PS استخراج شده از تصاوير ASAR. طيف رنگ آبى نشانگر ميزان جابهجايى در منطقه برداشت و طيف رنح قرمز نماينده ميزان جابهجايى در منطقه انباشتخى (رنكى در نسخه الكترونيكى) 

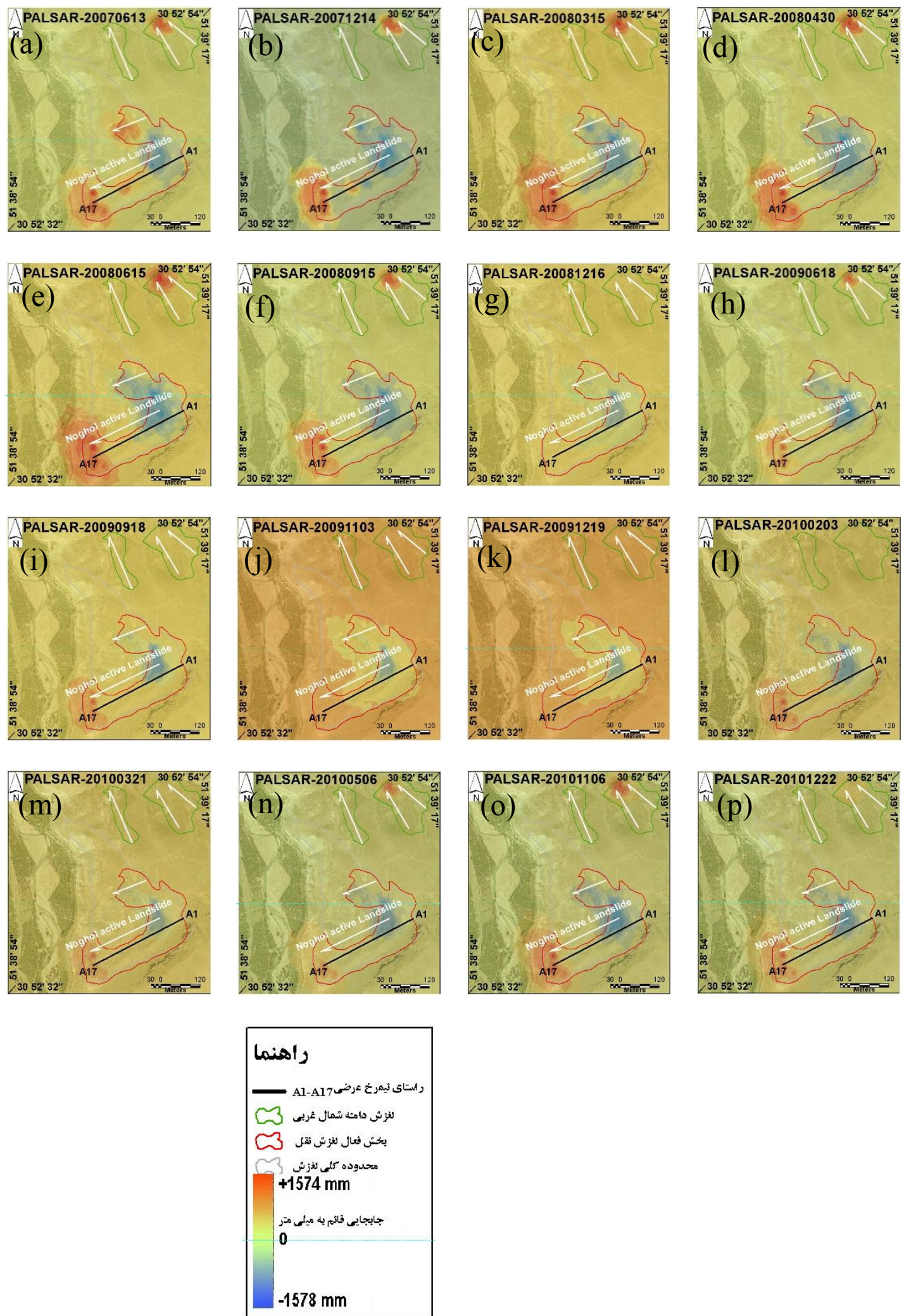

شكل 9. نقشههاى درونيابى حاصل از نقاط PS استخراج شده از تصاوير PALSAR. طيف رنخ آبى نشانخر ميزان جابهجايى در منطقه برداشت (منطبق با مناطق اعداد منفى) و طيف رنخ قرمز نماينده ميزان جابهجايى در منطقه انباشتخى (منطبق با مناطق اعداد مثبت) (رنخى در نسخه الكترونيكى) 


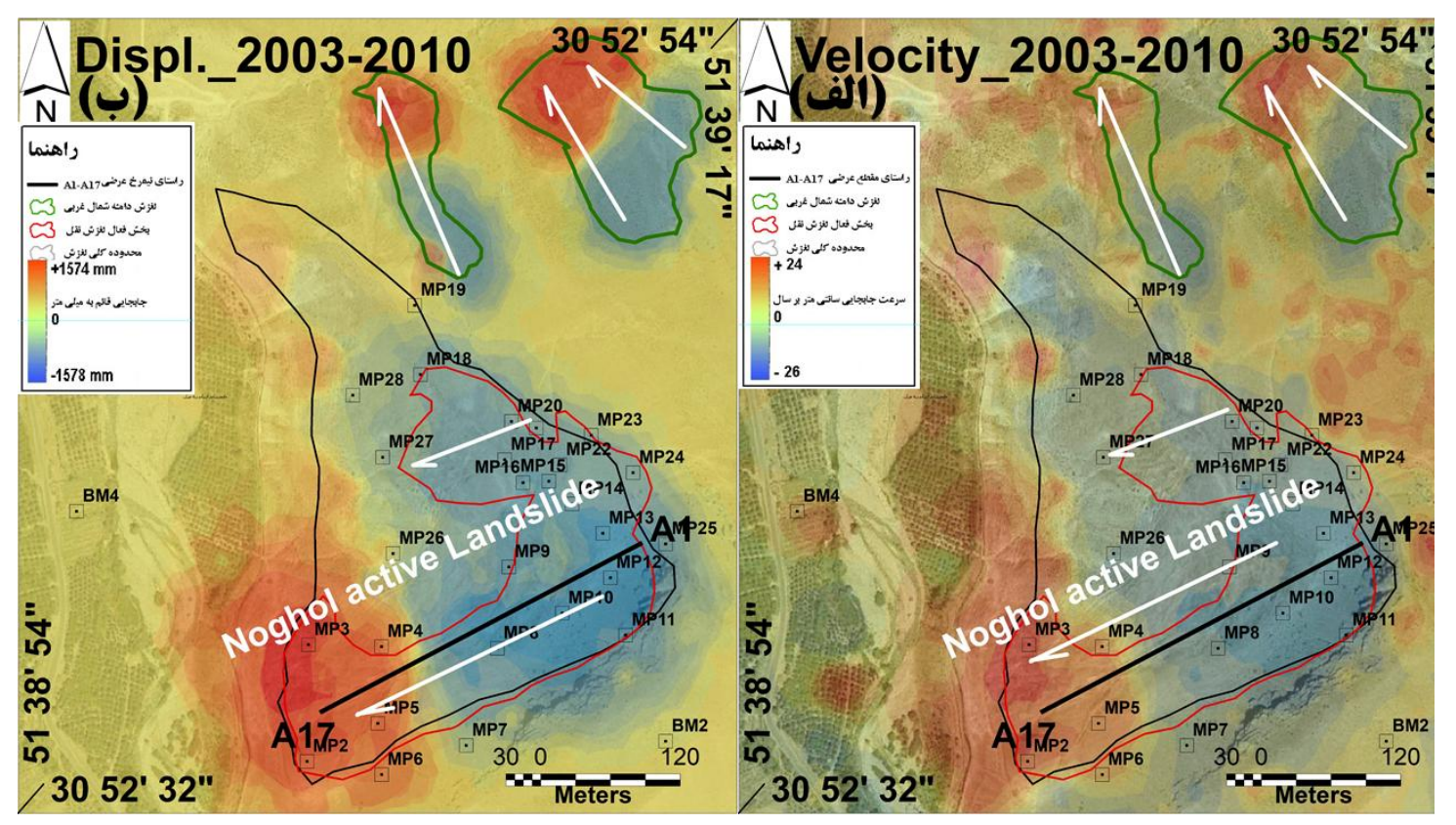

شكل ه ا. نرخ جابهجايى زمينلغزش نقل در منطقه برداشت (مناطق آبى رنغ) و انباشتخى (مناطق قرمز رنغ) و نمايش نيمرخ

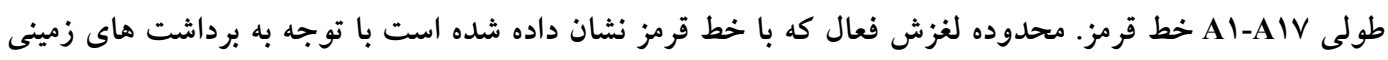
و تصاوير گو گل ارث ترسيم شده است (رنغى در نسخه الكترونيكى).

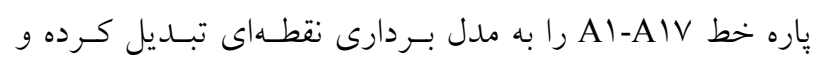

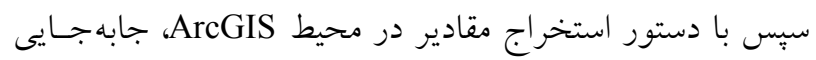

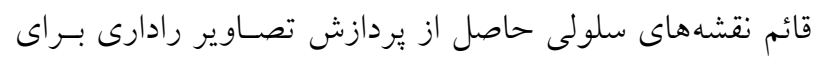

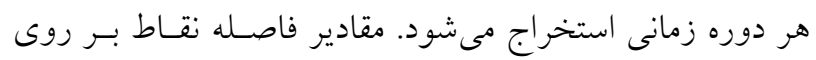

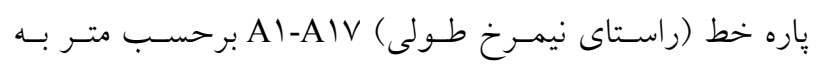

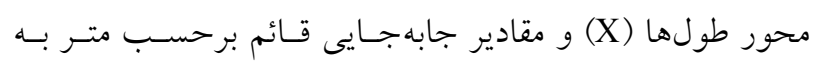

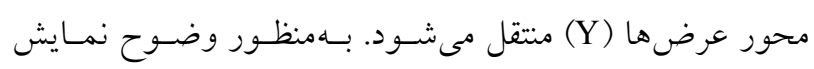

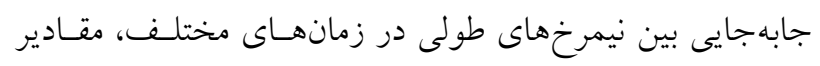

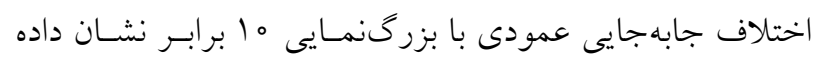

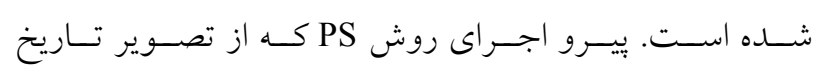

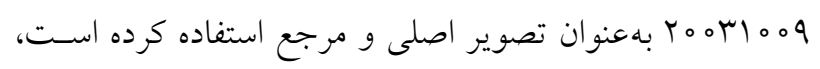

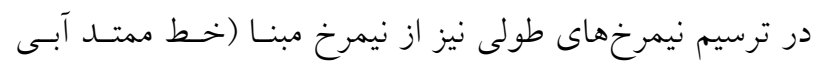

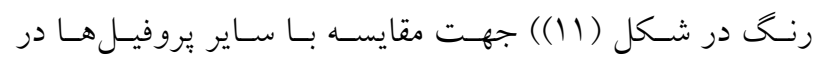

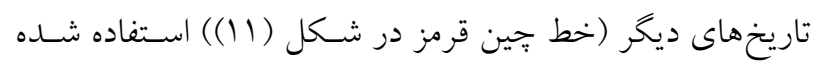

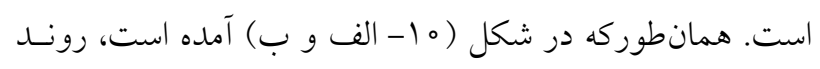

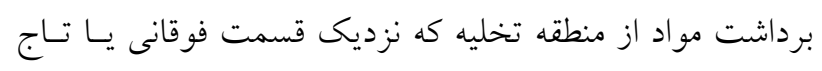

مى دهند) و موقعيت منــاطق برداشـت (نقـاط منفـى) و انباشـتـ

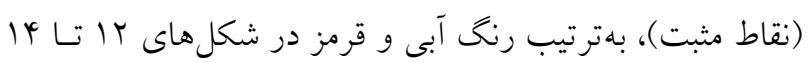

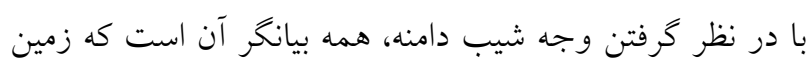

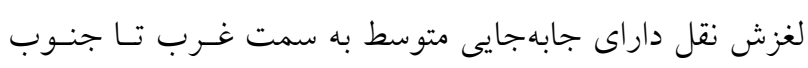

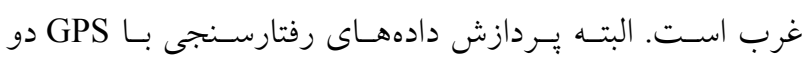

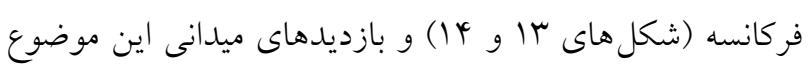

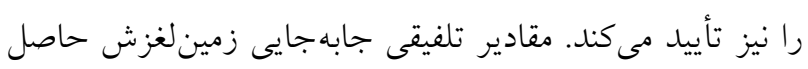

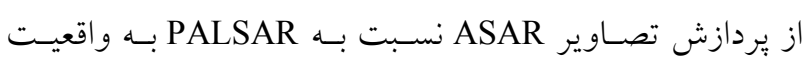

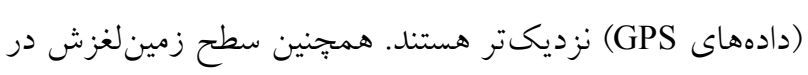
يردازش تصاوير ASAR بهتر نمايش داده مى نودد.

بر رسى مراحل مورفولوزيك سطح لغزش

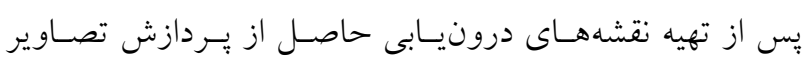

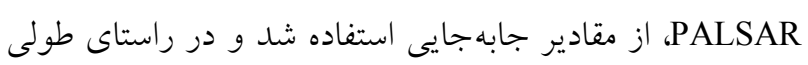

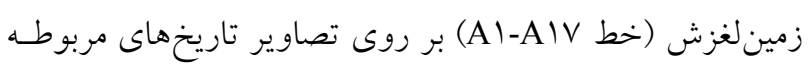
اقدام به تهيه نيمرخ طولى شد (شكل (I) (1). براى اين منظور ابتدا 

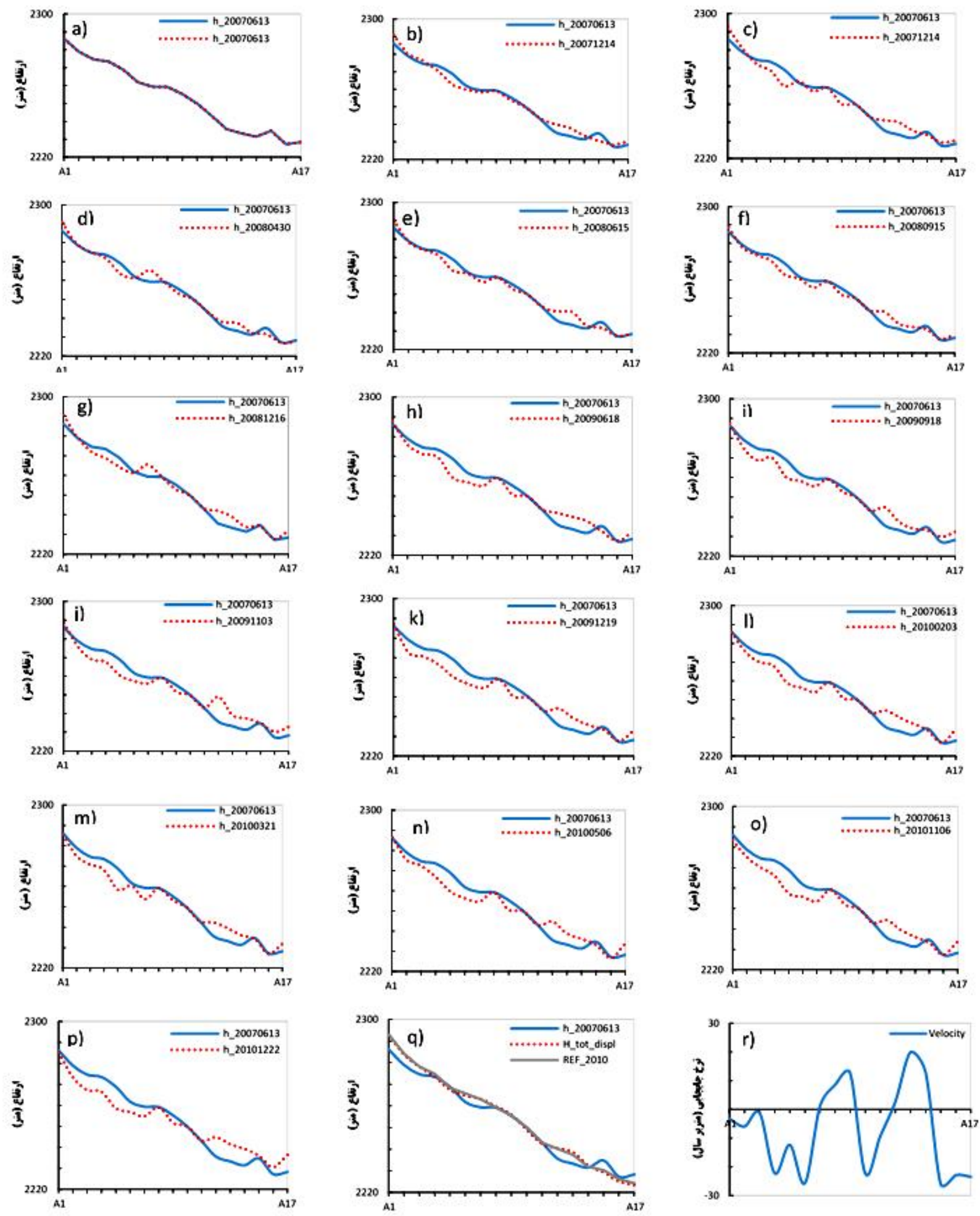

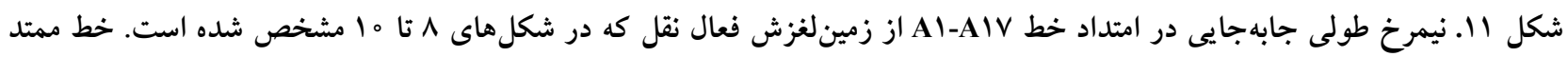

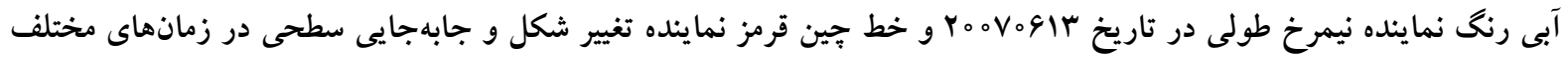
استخراج شده از روش PS تصاوير PALSAR (به منظور وضوح جابهجايى در نيمرخهاى طولى، اختلاف جابهجايى عمودى داراى بزرگنمايى •l برابر است) (رنغى در نسخه الكترونيكى) 


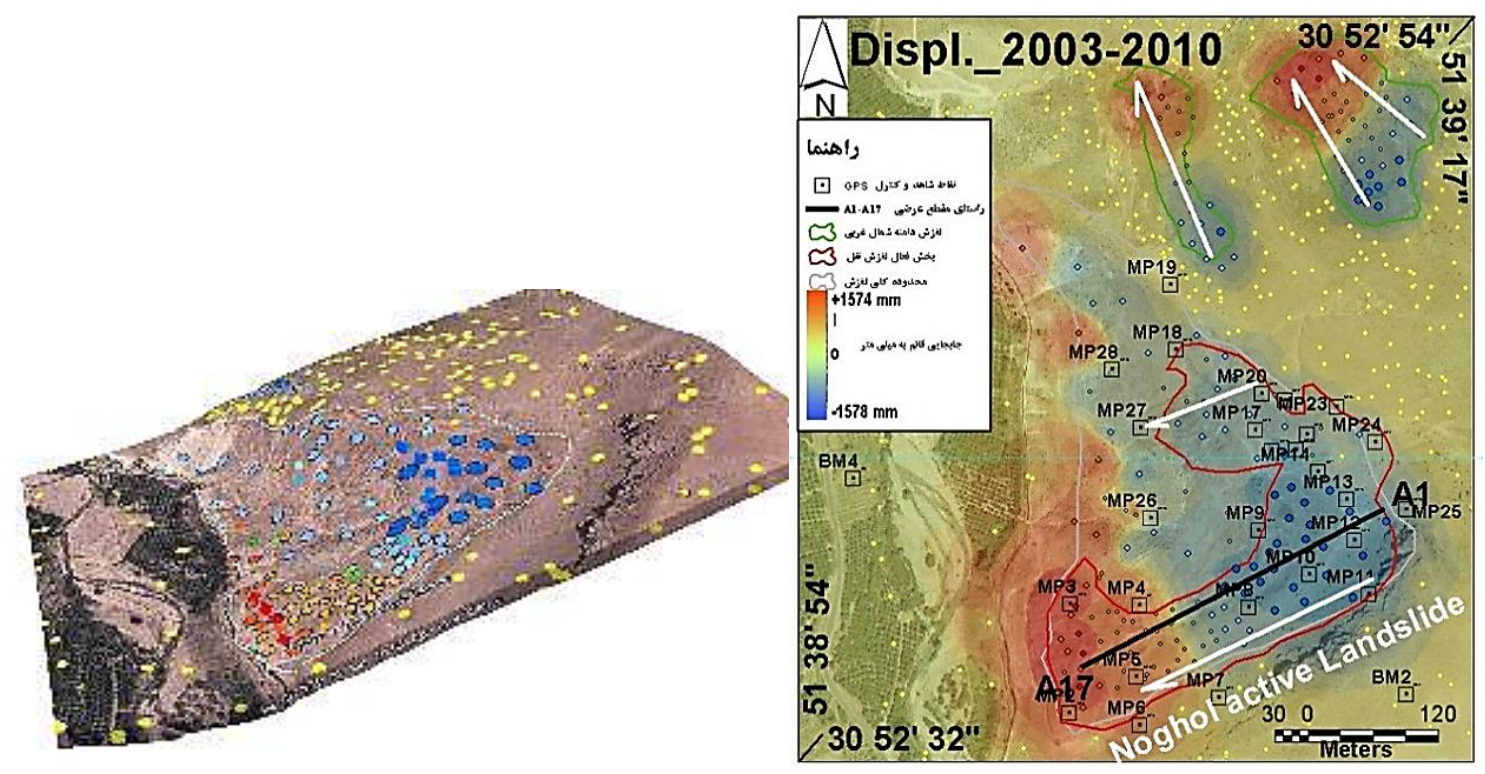

شكل ץا. تصوير محدوده مورد مطالعه در گو گل ارث و موقعيت نقاط شبكهاى ثابت و متحرك و PS بر روى آن

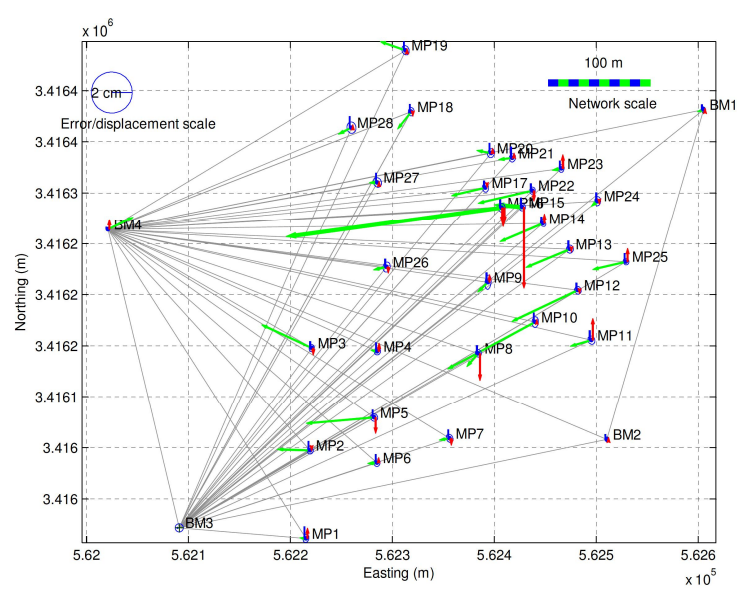

شكل 4 أ. جابهجايى هاى گرافيكى مسطحاتى و ارتفاعى نقاط كترل و شاهد (منطقه نقل - بين مرحله دوم و سوم)

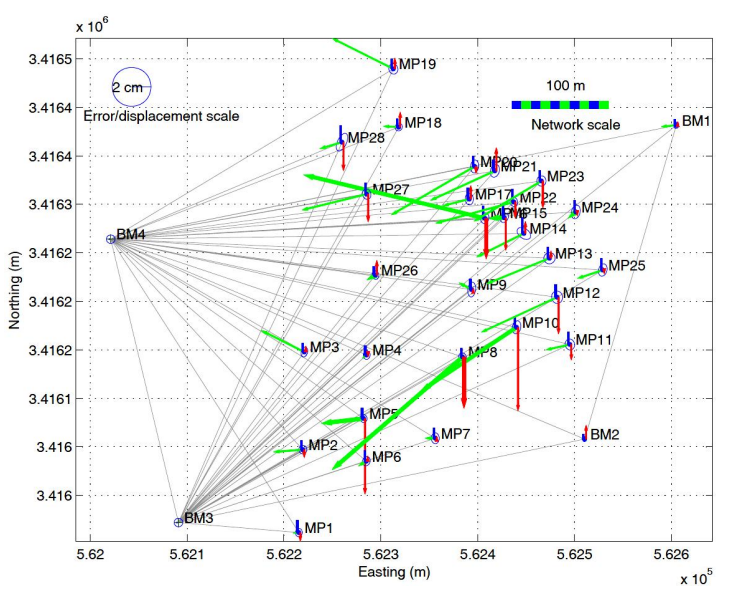

شكل rا. جابهجايىهاى گر افيكى مسطحاتى و ارتفاعى نقاط

كتترل و شاهد (منطقه نقل - بين مرحله اول و دوم)
است (شكل (1). همجنِنين ميزان تغييـرات جابـهجــيى قـائم در

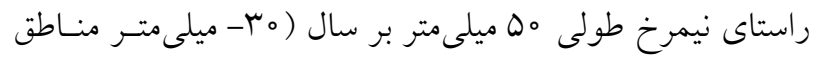

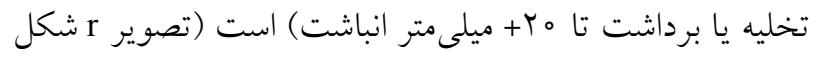

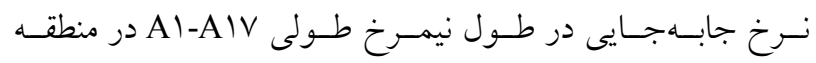

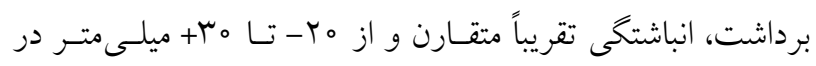

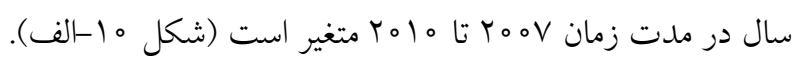

لغزش است با كذشت زمان توسعه يافته و به منطقـه انباشتـى

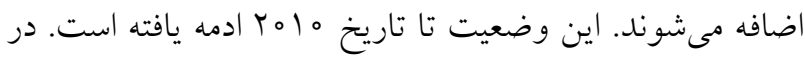

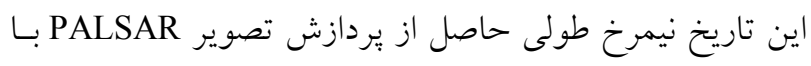

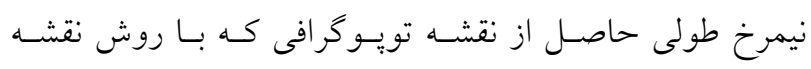

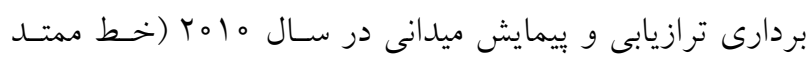

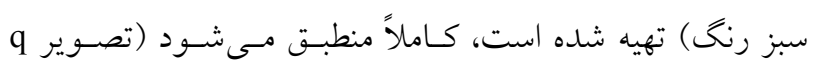
شكل (1)). اين موضوع بيانكر صحت نتايج PSI تصاوير رادار 


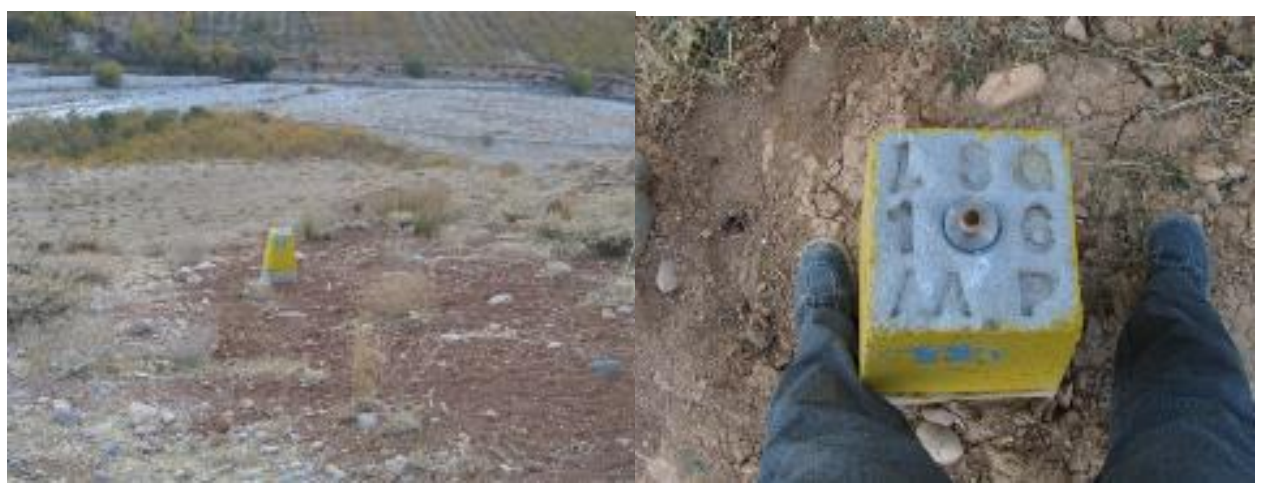

شكل 1ها. تصوير يكى از نقاط شاهد و ثابت روى توده لغزشى نقل

روى لغزش تعيين شد (شكل ه ا). اين نقاط تحت عنوان شـبكه نقاط شاهد (نشانهروى) منطقه زمينلغزشى بــا نـام MP نقاط

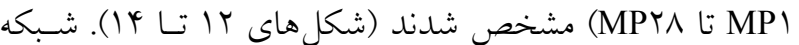

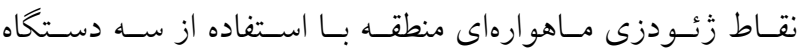
GPS/GNSS تكنيك تعيين موقعيت استاتيك مورد استفاده قـراركرفتـه اسـت. مدت مشاهدات هر خط مبنا مب دقيقه در نظركرفته شده اسـت. طرح مشاهداتى به كونهاى بود كه تمام نقـاط Rover از حسـداقل دو ايستخاه مرجع (در مرحله يردازش) تعيين مختصـات شـوند.

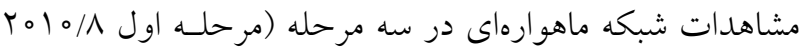

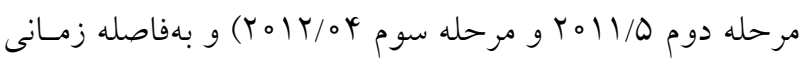
حدود ه ا ماه انجام يذيرفته است. مشاهدات مرحله دوم و سوم نيز براى \^ نقطه انجام شده است. نرمافزار يُردازش مورد استفاده LeicaGeoOffice5 (LGO) است. اين نرمافزار براى يــردازش خـط مبناهــا اسـتفاده شـــه و خروجـى يـــدازش بــراى مراحـل سرشـكنى و ميكروزئسودزى

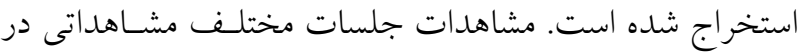
هر مرحله با انتخاب مناسب يارامترهاى مربوطه بردازش شد. يسس از محاسـبه مختصــات نقــاط در دو مرحلــه ميـزان جابه جايىها محاسبه مى شود. همجنين با استفاده از قانون انتشار خطاها ماتريس واريانس - كواريانس، جابهجايى ها قابل محاسبه است. جابهجايى هاى مسطحاتى و ارتفاعى نقاط كتترل و شـاهد روى منطقه زمين لغزش بههمراه ابعاد بيضى خطاى جابهجايى و

\section{PS اعتبارسنجى نتايج حاصل از يردازش} در بسيارى از يزوهشهاى بايش زمين لغزش بـهـمــى تصـاوير رادار، دو اسـتراتزى بـراى اعتبارسـنجى نتـايج بـهـــار مسىرود. استراتزى اول مقايسه يك زمين لغزش در يــردازش سـرىهـاى تصاوير كذرهايى همجوار با دو جهت مدارى خـــريايين و بـالا

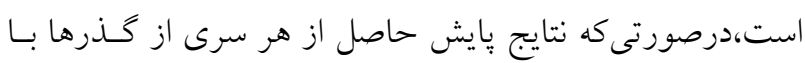
سرى گذر همجوار ديخر يـا حركـت مـدارى گـذريايين و بـالا داراى روند يكسان باشند، مىتوان نتايج حاصل را معتبر دانست (T ا و YV). در اين يزوهش در بخـش ارزيـابى و تفسير نتسايج

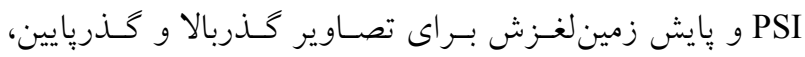
نتايج بردازش هر دو سرى تصوير بيانخر حركت لغزش بهميزان

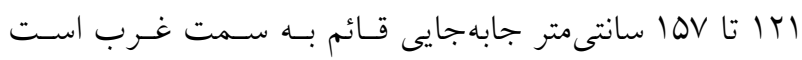
(شكل هاى م و 9 9). (ش) استراتزى دوم استفاده از تكنيـكهـاى بــايش زمسين لغــش به كمك GPS بهروش RTK است. خوشبختانه در منطقسه مـورد مطالعه زمين لغزش نقل در قالب طـرح مطالعـاتى رفتـارسـنجى زمينلغزش تحت پِايش قرار گرفته است (r و †).

\section{GPS نتايج دادههاى} براى بررسى رفتارسنجى منطقه، از سيستم تعيـين موقعيـتيـاب جهانى GPS بهصورت اسـتاتيك اسـتفاده شـده اسـت. در ايسن تكنيك جهار نقطه ثابت (فرض) با نام BM در قالب نقاط شبكه

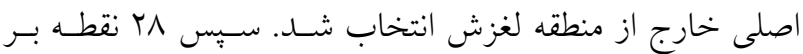


مطالعه اين تحقيق، روش PS براى دادههاى ASAR از نقطهنظر

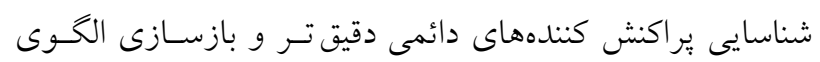

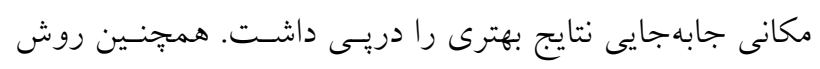

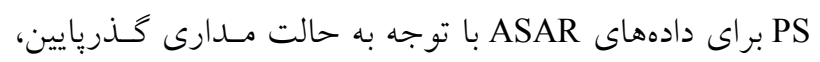

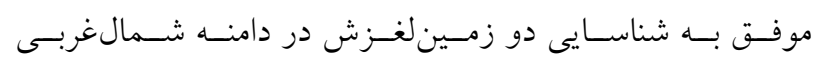

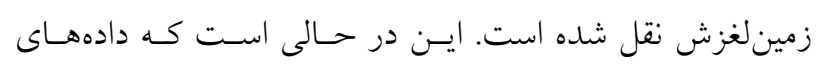

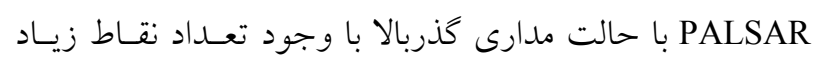

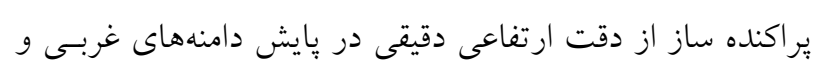
شمال غربى برخوردار نيست.

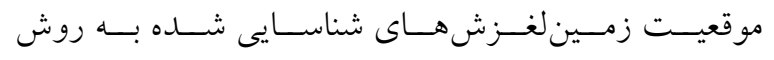
تداخل سنجى رادارى با اطلاعات زمينى جمع آورى شده، مقايسه

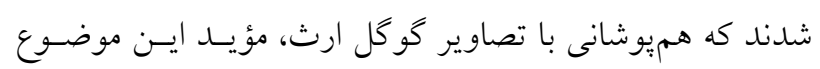

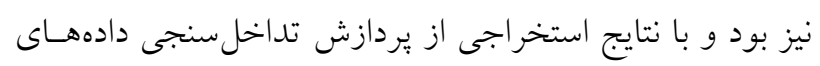

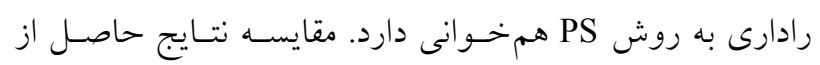

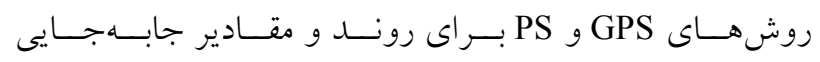

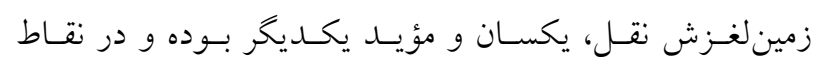

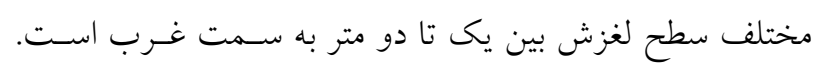

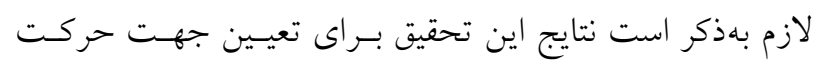

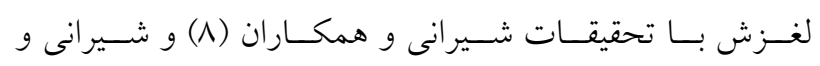

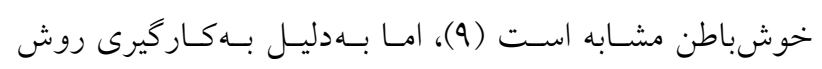

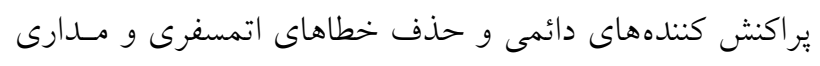
بهدليل ماهيت ذاتى اين روش در افزايش دقت تعيين جابهجايى دئي

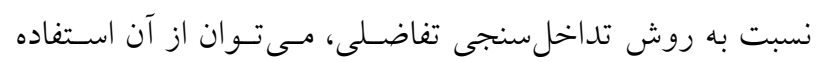

در اين مقاله با استفاده از مزاياى تكنيك براكنش كنتـدهــاى

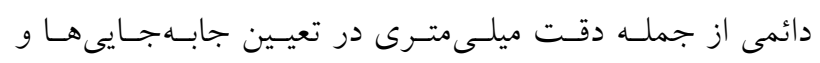

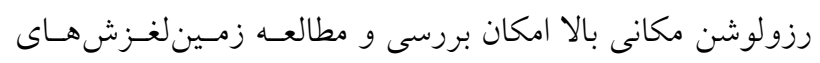

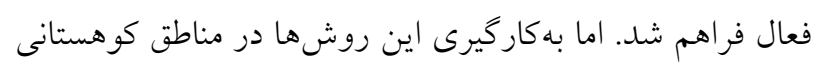

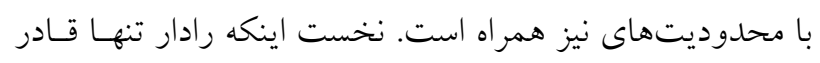
به تشخيص جابهجايى ها در راستاى خط ديد است. در نتيجه در

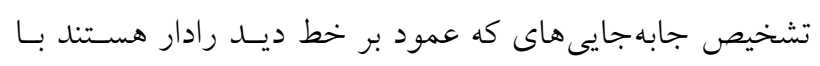

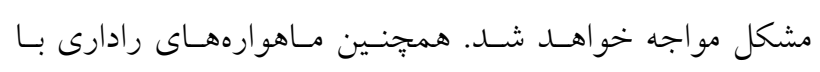

خطاى تعيين جابهجايى ارتفاعى در سطح و فاصله اطمينـان 90

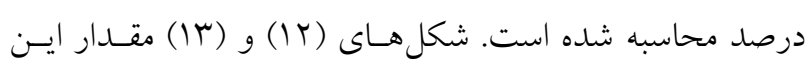

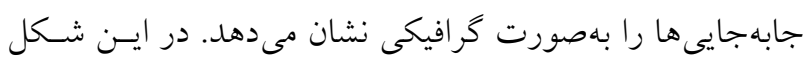

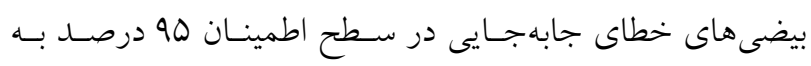

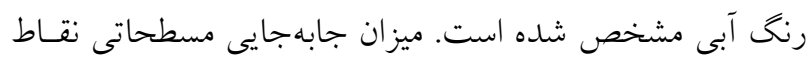

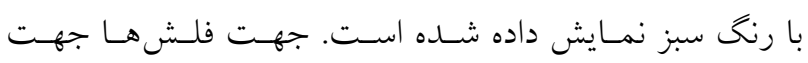
جابهجايىهاست و مقياس بردار جابهجايى ها در شـكل هـا ارائسه.

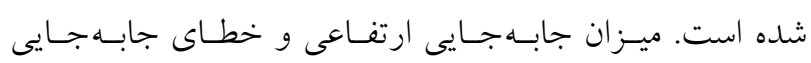

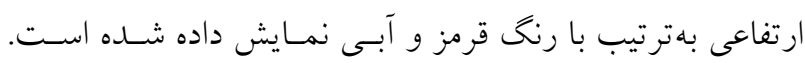

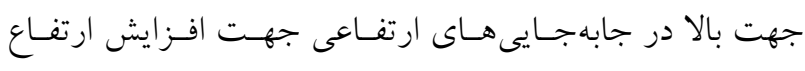

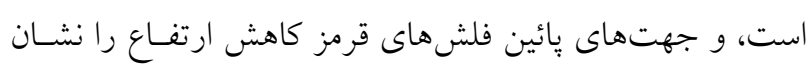
مى دهل.

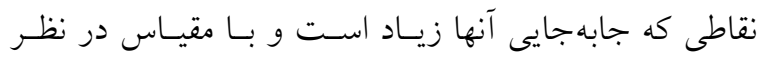

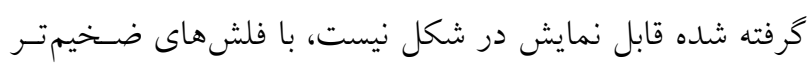

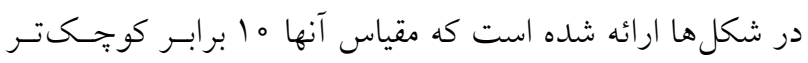

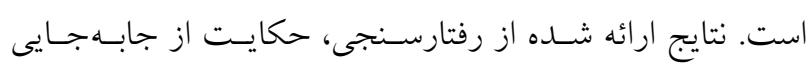

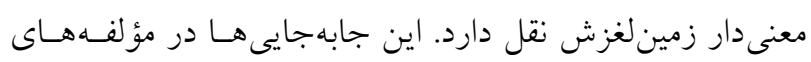

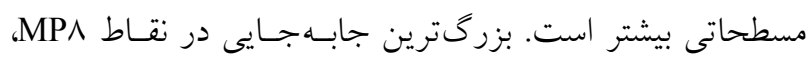

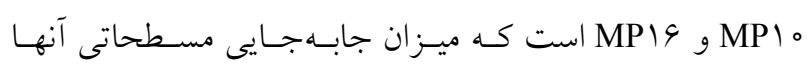
حدود يكى تا دو متر است. جابه جايى مسطحاتى منطقه بيشتر به سـمت غـرب اسـت. در مرحلـه سـوم نقطـه MP16 همدجنـان جابهجايى قابل توجهى را نشان مىدهد.

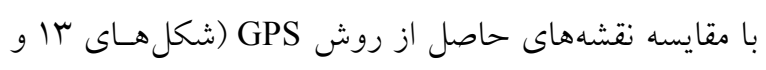

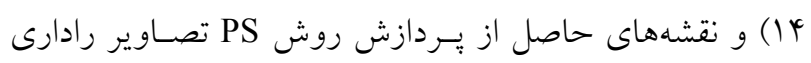

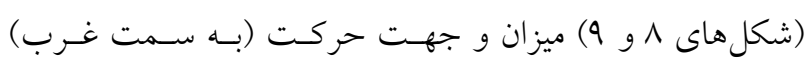
توسط هر دو روش مشابه است.

\section{نتيجه گيرى}

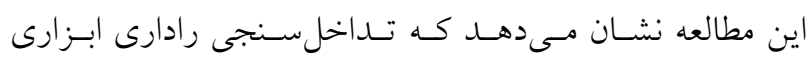

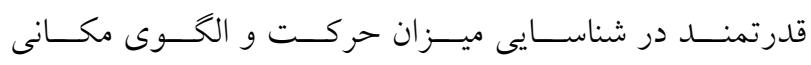

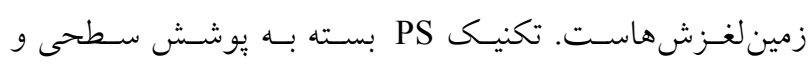

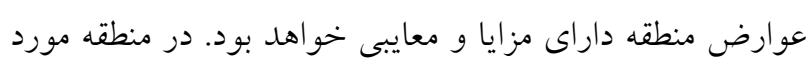


زمينلغزش شده است. استفاده از تلفيق دادههاى رادار در دو كذر

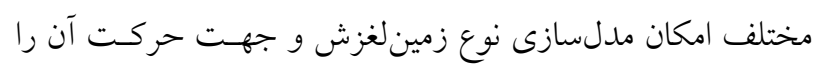

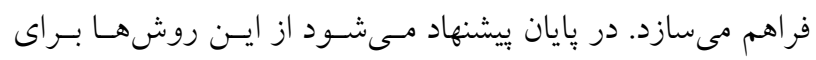
شناسايى زمينلغزشهاى فعال كشور استفاده شود.

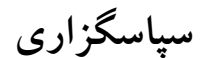

اين مقاله بخشى از نتايج طرح يزوهشى در حال اجـرا در مركـز

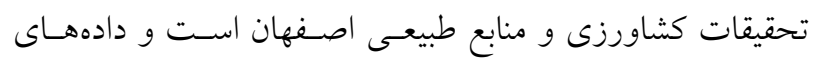

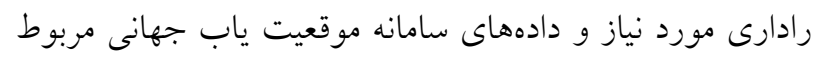

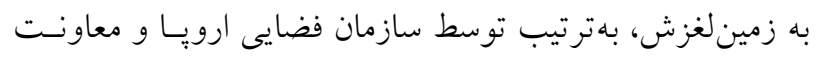

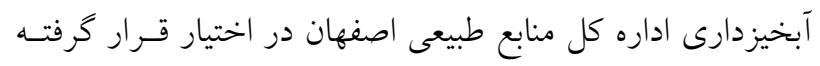

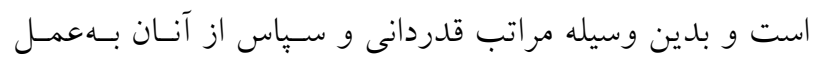

مى آيد.

راستاى شـمالى -جنـوبى، در مــدارهاى نزديـك بـه قطبـى ديـــ

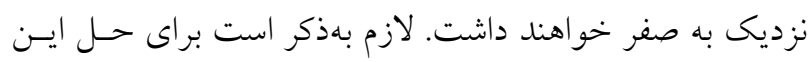

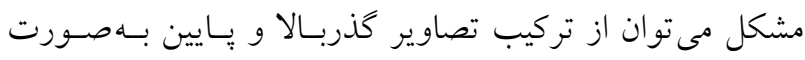

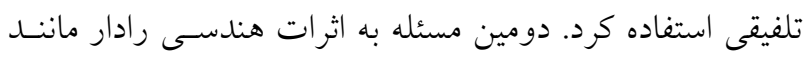

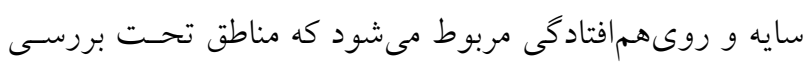

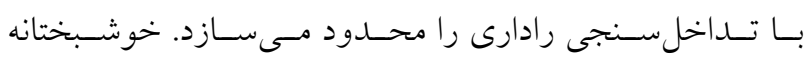
زمين لغزش مورد مطالعه در شيبهايى كه تحت تأثير اين خطاها

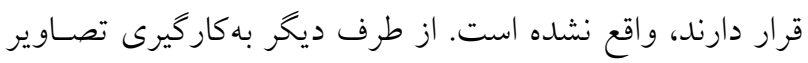

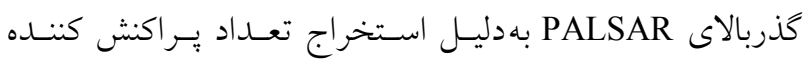
دائمسى بيشـتر نسـبت بـه تصـاوير كـذريايين ASAR، امكــان

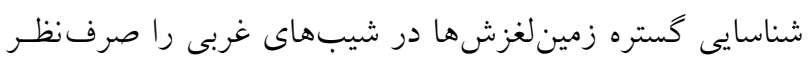
از دقت نيز فراهم مى سازد. در اين تحقيق بهكاركيرى تلفيقسى تصـاوير كـذربـالا و يـايين

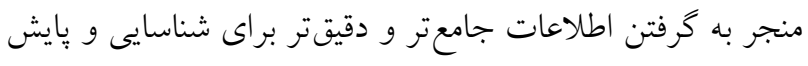

\section{منابع مورد استفاده}

ا. آقانباتى، ع. هیrا. زمين شناسى /يران، سازمان زمينشناسى كشور. تهر ان.

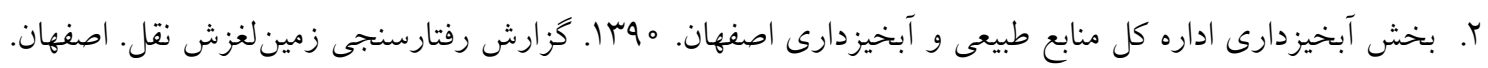

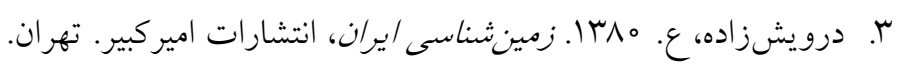

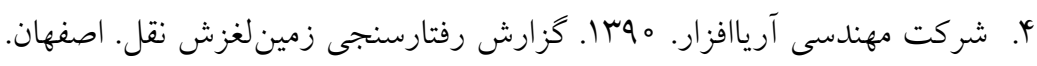

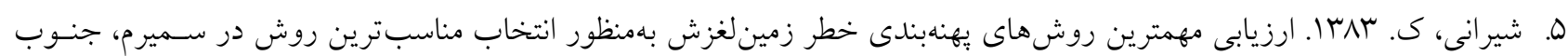
اصفهان، طرح تحقيقاتى وزارت جهاد كشاورزى. اصفهان.

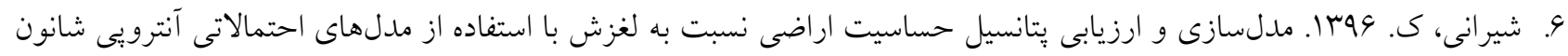

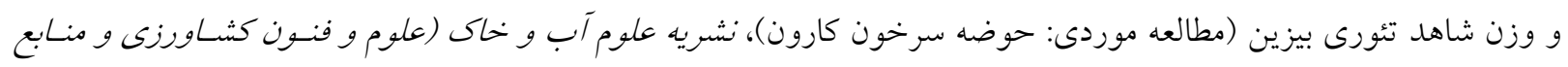

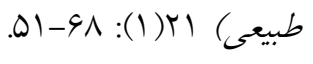

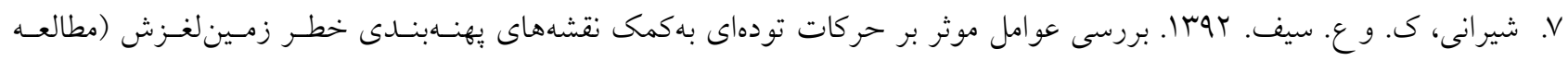

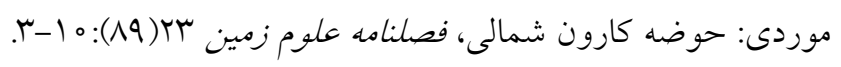

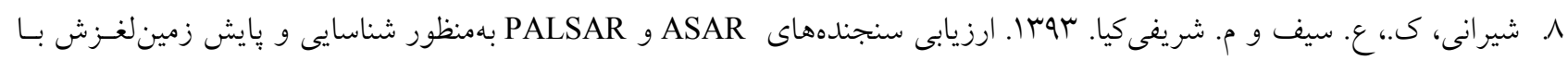

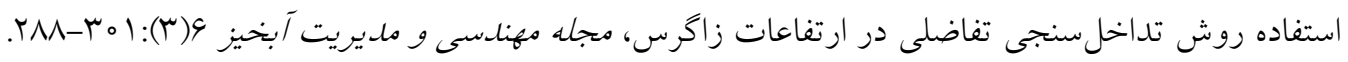

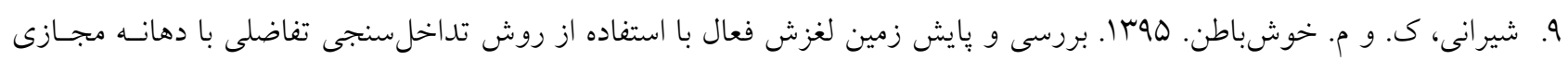

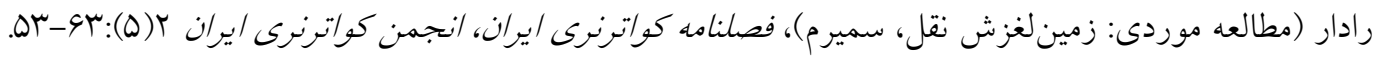

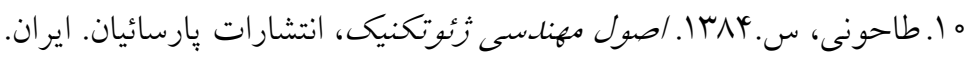


11. Blanco-Sanchez, P., J. J. Mallorqui, S. Duque and D. Monells. 2008. The coherent pixels technique (cpt): an advanced dinsar technique for nonlinear deformation monitoring. Pure Applied Geophysics 165: 1167-1193.

12. Bovenga, F., J. Wasowski, D. O. Nitti, R. Nutricato and M. T. Chiaradia. 2012. Using COSMO/SkyMed X-band and ENVISAT C-band SAR interferometry for landslides analysis. Remote Sensing of Environments 119: 272285.

13. Colesanti, C. and J. Wasowski. 2006. Investigating landslides with space-borne Synthetic Aperture Radar (SAR) interferometry. Engineering Geology 88: 173-199.

14. Colesanti, C., A. Ferretti, C. Prati and F. Rocca. 2003. Monitoring landslides and tectonic motions with the Permanent Scatterers Technique Engineering Geology 68: 3-14, 2003.

15. Costantini, M., S. Falco, F. Malvarosa and F. Minati. 2008. A new method for identification and analysis of persistent scatterers in series of SAR images. In: Proceedings of the IEEE International Geoscience \& Remote Sensing Symposium (IGARSS'08), Boston, MA, USA. PP: 449-452.

16. Crosetto, M., E. Biescas, J. Duro, J. Closa and A. Arnaud, 2008. Generation of advanced ERS and Envisat interferometric SAR products using the Stable Point Network technique. Photogrammetric Engineering \& Remote Sensing 74: 443-451.

17. Crosetto, M., O. Monserrat, M. Cuevas and B. Crippa. 2011. Spaceborne differential SAR interferometry: data analysis tools for deformation measurement. Remote Sensing 3: 305-318.

18. Cruden, D. M. and D. J. Varnes. 1996. Landslide types and processes. PP: 36-75. In: A. K. Turner and R. L. Schuster (Eds.), Landslides: Investigation and Mitigation, Special Report 247-Transportation Research Board, National Research Council; National Academy Press: Washington, DC, USA.

19. Farina, P., D. Colombo, A. Fumagalli, F. Marks and S. Moretti. 2006. Permanent Scatterers for landslide investigations: outcomes from the ESA-SLAM project. Engineering Geology 88: 200-217.

20. Ferretti, A., A. Fumagalli, F. Novali, C. Prati, F. Rocca and A. Rucci. 2011. A new algorithm for processing interferometric data-stacks: SqueeSAR IEEE Trans. Geosciences and Remote Sensing 49: 3460-3470.

21. Ferretti, A., C. Prati and F. Rocca. 2000. Nonlinear subsidence rate estimation using Permanent Scatterers in differential SAR interferometry. Geosciences and Remote Sensing 38: 2202-2212.

22. Ferretti, A., C. Prati and F. Rocca.2001. Permanent Scatterers in SAR interferometry. IEEE Trans. Geosciences and Remote Sensing 39: 8-20.

23. Glade, T. and M. J. Crozier. 2005. A review of scale dependency in landslide hazard and risk analysis. PP: 75-138. In: T. Glade, M. G. Anderson and M. J. Crozier (Eds.), Landslide Risk Assessment. John Wiley. England.

24. Herrera, G., D. Notti, J. C. Garcia-Davalillo, O. Mora, G. Cooksley, M. Sanchez, A. Arnaud and M. Crosetto. 2011. Analysis with C- and X-band satellite SAR data of the Portalet landslide area. Landslides 8: 195-206.

25. Hooper, A., P. Segall and H. Zebker. 2007. Persistent scatterer interferometric synthetic aperture radar for crustal deformation analysis, with application to Volcan Alcedo, Galapagos. . Journal of Geophysics and Remote Sensing 112: B07407.

26. Lanari, R., O. Mora, M. Manunta, J. J. Mallorqui, P. Berardino and E. Sansosti. 2004. A small baseline approach for investigating deformation on full resolution differential SAR interferograms. IEEE Trans. Geosciences and Remote Sensing 42: 1377-1386.

27. Liu, P., Z. Li, T. Hoeya, C. Kincal, J. Zhang, Q. Zeng and J. P. Muller. 2013. Using advanced InSAR time series techniques to monitor landslide movements in Badong of the Three Gorges region, China. Journal of Applied Earth Observation and Geoinformation 21: 253-264.

28. Lu, P., N. Casagli, F. Catani and V. Tofani. 2012. Persistent Scatterers Interferometry hotspot and cluster analysis (PSI-HCA) for detection of extremely slow-moving landslides. Remote Sensing 33: 466-489.

29. Mantovani, F., R. Soeters and C. Van Westen. 1994. Remote sensing techniques for landslide studies and hazard zonation in Europe. Geomorphology 15: 213-225.

30. Perissin, D. and T. Wang. 2012. Repeat-pass SAR interferometry with partially coherent targets. IEEE Trans. Geosci. Geosciences and Remote Sensing 50: 271-280.

31. Righini, G., V. Pancioli and N. Casagli. 2012. Updating landslide inventory maps using Persistent Scatterer interferometry (PSI). International Journal of Remote Sensing 33: 2068-2096.

32. Scaioni, M., L. Longoni, V. Melillo and M., Papini. 2014. Remote sensing for landslide investigations: an overview of recent achievements and perspectives. Remote Sensing 6, doi: 10.3390/rs60x000x.

33. Singhroy, V. 2005. Remote Sensing for Landslide Assessment: Chapter 16, in Book on Landslides Hazard and Risk edited by Glade Anderson and Crozier. Wiley Press. England.

34. Strozzi, T., U. Wegmuller, H. R. Keusen, K. Graf and A. Wiesmann. 2006. Analysis of the terrain displacement along a funicular by SAR interferometry. Geosciences and Remote Sensing 3: 15-18.

35. Tofani, V., S. Segoni, A. Agostini, F. Catani and N. Casagli. 2013. Technical note: Use of remote sensing for landslide studies in Europe". Nat. Natural Hazards and Earth Systems 13: 1-12. 
36. Tomas, R., G. Herrera, J. M. Lopez-Sanchez, F. Vicente, A. Cuenca and J. J. Mallorqu. 2010. Study of the land subsidence in Orihuela City (SE Spain) using PSI data: distribution, evolution and correlation with conditioning and triggering factors. Engineering Geology 115(1-2): 105-121.

37. Varnes, D. J. 1978. Slope Movement Types and Processes, In Special Robert 176: Landslides Analysis and Control PP. 11-33. In: R. L. Schuster and R. J. Krizer (Eds.), TRB, National Research Council Washington.

38. Varnes, D. J. 1984. The IAEG Commission on Landslides and other Mass-Movements. Landslide Hazard Zonation: A Review of Principles and Practice. The UNESCO Press, Paris.

39. Wasowski, J. and F. Bovenga. 2014. Investigating landslides and unstable slopes with satellite Multi Temporal Interferometry: Current issues and future perspectives. Engineering Geology 174: 103-138.

40.Zebker, H. A., P. A. Rosen and S. Hensley. 1997. Amospheric effects in interferometric synthetic aperture radar surface deformation and topographic maps. Journal of Geophysical Research 102(B4): 7547-7563.

41. Zhao, C., Z. Lu, Q. Zhang and J. Fuente. 2012. Large-area landslide detection and monitoring with ALOS/PALSAR imagery data over Northern California and Southern Oregon, USA, Remote Sensing of Environment 124: 348-359. 


\title{
Detection, Monitoring and Mechanism of Landslide using Persistent Scattering Ineterferometry (PSI)
}

\author{
K. Shirani $i^{*}$ \\ (Received: June 27-2016 ; Accepted: October 30-2017)
}

\begin{abstract}
The persistent scattering interferometry (PSI) technique is a valuable tool in displacements' monitoring of earth's surface. The persistent scattering interferometry (PSI) based on persistent scatterrer (PSInSAR) is one of the techniques used to reduce constraints (temporal and spatial incoherency). It is based on persistent scatterer and monitor displacement of only the pixels with timely-constant properties of scatterer. In order to detect and monitor landslides, two time series SAR data sets including PALSAR ascending images from 2007 to 2010 and ASAR images from 2003 to 2010 with C-band and L-band wavelength were applied, respectively. Also, the PSI technique was implemented in a landslide near Noghol village, Padena, Semirom of Isfahan province. The results revealed that both PALSAR and ASAR data set were efficient in identifying Noghol landslide. The results obtained from ASAR and PALSAR images processing (with the values of $1253 \mathrm{~mm}$ and $1578 \mathrm{~mm}$ in two stages of time 4 and 7 years, respctively) were compared. The obtained vertical displacement's rate of the landslide by using ASAR data was more suitable because of its descending orbit. However, PALSAR images that indetified more persistent scatterrer points were better in the detection of the landslide area. The results of GPS and PSInSAR techniques revealed that landslide displacement values and aspect were the same, confirming 135 centimeters of displacement to the west aspect. Finally, a combination of radar data in two different passes provided the possibility of monitoring the mechanism of landslide and its movement direction.
\end{abstract}

Keywords: Interferometry, Persistent Scatterrer, RADAR, PALSAR, ASAR, Landslide

1. Soil Conservation and Watershed Management Research Department, Isfahan Agricultural and Natural Resources Research and Education Center, AREEO, Isfahan, Iran.

*: Corresponding Author, Email: K.Shirani@areeo.ac.ir 